\title{
Upwelling characteristics and nutrient enrichment of the Kangaroo Island upwelling region, South Australia
}

\author{
L.E. Richardson ${ }^{\text {a,b, }}$, J.F. Middleton ${ }^{b}$, N.P. James ${ }^{\text {b,c }}$, T.K. Kyser ${ }^{c, 1}$, B.N. Opdyke ${ }^{a}$ \\ ${ }^{a}$ Research School of Earth Sciences, Australian National University, Canberra, ACT, 0200, Australia \\ ${ }^{\mathrm{b}}$ South Australian Research and Development Institute, Aquatic Sciences, West Beach, SA, 5024, Australia \\ c Department of Geological Sciences, Queen's University, Kingston, ON, K7L 3N6, Canada
}

\section{A R T I C L E I N F O}

\section{Keywords:}

Water mass

Upwelling

Nutrients

NOx

Phosphate

Silicate

South Australia

Kangaroo Island

Nutrient enrichment

Interannual variation

\begin{abstract}
A B S T R A C T
An analysis is presented of hydrographic and nutrient data collected over three years for the Kangaroo Island upwelling region, Lincoln Shelf, South Australia, to determine the signature of upwelled water, depth of upwelling and the source water mass being brought onto the shelf. Strong upwelling seasons were recorded during the 2007-2008 and 2009-2010 summers, while the summer of 2008-2009 had only one weak upwelling event. Strong upwelling events during February and March 2008 and February and March 2010 recorded temperatures and salinities as low as $10.4^{\circ} \mathrm{C}$ and 34.85 , and $\mathrm{NO}_{\mathrm{x}}$ and phosphate concentrations as high as 13.35 and 0.94 $\mu \mathrm{mol} / \mathrm{L}$, respectively, at $105 \mathrm{~m}$ on the shelf. Upwelled water properties matched slope water properties between 240 and $370 \mathrm{~m}$, indicating water can be upwelled over depths of $200 \mathrm{~m}$ or more. Upwelling from these depths sources South Australian Basin Central Water of Southern Ocean origin, which is transported west along the slope by the Flinders Current System. New results for nutrients show average values of $\mathrm{NO}_{\mathrm{x}}$ and phosphate during months of strong upwelling to be 6.1 times and 4.6 times greater, respectively, than during winter months, and that upwelled water can have nutrient concentrations up to 90 times higher than those in summer surface waters. Strong relationships between temperature and nutrients on the slope can help estimate nutrient concentrations supplied to the shelf during upwelling events. Upwelled water was also low in silicate, a signature of Southern Ocean water masses, which has implications for phytoplankton community structure and diatom abundance on the shelf.
\end{abstract}

\section{Introduction}

The shelf area between the Bonney Coast and the eastern Great Australian Bight (GAB; Fig. 1) is a significant oceanographic and ecological region, where sporadic, wind-driven upwelling during summer and early autumn advects nutrients onto a predominantly oligotrophic shelf (Lewis, 1981; Schahinger, 1987; Kämpf et al., 2004; Ward et al., 2006). Such upwelling brings cool, nutrient-rich water onto the shelf and leads to high levels of primary productivity (Ward et al., 2006; van Ruth et al., 2010a). This region supports the highest densities of sardine, anchovy and other small planktivorous fishes in Australian waters (McLeay et al., 2003), which provide food for higher trophic level species (Goldsworthy et al., 2013). Eleven major commonwealth and state-run fisheries operate in this area, and all are dependent on the supply of nutrient rich water from upwelling (McLeay et al., 2003).
Two major current systems influence the continental shelf and slope in this area. The eastward flowing Leeuwin Current System extends from North West Cape, Western Australia, to southern Tasmania (Ridgway and Condie, 2004), and is an oligotrophic surface current that is strongest in winter and weakest in summer (Rochford, 1986). The South Australian Current forms part of the Leeuwin Current System, transporting Subtropical Surface Water year-round from the eastern GAB to Bass Strait (Ridgway and Condie, 2004; Richardson et al., 2018).

The Flinders Current System flows west below this surface current along the continental slope (Bye, 1972, 1983) and is strongest between 400 and $600 \mathrm{~m}$ water depth (Middleton and Cirano, 2002). New research (Richardson et al., 2019) defines the Flinders Current System as a combination of Sverdrup transport, the Tasman Outflow, and the slope-trapped Flinders Current. This current system transports South Australian Basin Central Water, Tasmanian Subantarctic Mode Water

\footnotetext{
* Corresponding author. Research School of Earth Sciences, Australian National University, Canberra, ACT, 0200, Australia.

E-mail address: laura.richo@gmail.com (L.E. Richardson).

1 Deceased after majority of manuscript completed.
} 
and Antarctic Intermediate Water north across the Subtropical Front and west along the Australian upper continental slope (Barker, 2004; McCartney and Donohue, 2007; Richardson et al., 2019). The interface between the Leeuwin Current System and the Flinders Current System in the Kangaroo Island region is as shallow as $200 \mathrm{~m}$ in summer when isotherms are raised due to upwelling, and deepens to almost $400 \mathrm{~m}$ in winter due to outflow of dense shelf water from the GAB and Spencer Gulf (Richardson et al., 2019).

The Flinders Current is a northern boundary current system that has similarities to the world's productive eastern boundary current systems off California, Peru and southern Africa (Ward et al., 2006). Several authors have suggested that the Flinders Current supplies water to the shelf during upwelling events (Ward et al., 2006; Middleton and Bye, 2007; Richardson et al., 2009). This inference was confirmed in a recent water mass analysis of the Lincoln Shelf by Richardson et al. (2018), who found that upwelled water can come from $300 \mathrm{~m}$ and match properties of South Australian Basin Central Water, which is transported by the Flinders Current System (Richardson et al., 2019). During upwelling events on the Lincoln Shelf, levels of primary, secondary and fish production are within the lower ranges observed during upwelling events in the eastern boundary current systems (Ward et al., 2006; van Ruth et al., 2010a). Despite the region's oceanographic, ecological and commercial importance and its similarities to other well-studied eastern boundary current systems, this upwelling region has not been studied extensively. There is little information on the interannual variability of upwelling events, or how the source depth of upwelled water varies, which controls the level of nutrients supplied to the shelf (Richardson et al., 2019).

Modelling and hydrographic analyses indicate that water is upwelled onto the narrow shelves of Kangaroo Island and the Bonney Coast. A subsurface pool of upwelled water, referred to as the Kangaroo Island Pool (McClatchie et al., 2006), forms southwest of Kangaroo Island during an upwelling event, and this water is then advected west into the eastern GAB by northwesterly coastal currents (Kämpf et al., 2004; McClatchie et al., 2006; Richardson et al., 2018). Subsequent upwelling favourable winds then raise this water to the surface off southwestern Eyre Peninsula (Kämpf et al., 2004). Our current understanding of the source depth of upwelling is based on a limited number of hydrographic profiles. Hydrographic sections off Robe (Bonney Coast, $140^{\circ} \mathrm{E}$ ) during upwelling events in 1983 and 1984 (Schahinger, 1987) suggest water upwelled onto the shelf seafloor comes from 250 to $300 \mathrm{~m}$, and therefore water upwells over depths of 100-180 m. Off Kangaroo Island, Middleton and Platov (2003) simulate upwelling occurring from $150 \mathrm{~m}$, whereas modelling by Kämpf (2010) suggests that submarine canyons play an important role in upwelling, bringing water from an average depth of $310 \mathrm{~m}$ through the canyons onto the shelf. Variations in the strength of upwelling between years could be the reason for these differences in source depth.

Few studies have measured nutrient concentrations or considered the chemical properties of upwelled water in the region. On the Bonney Coast, Lewis (1981) found that nitrate concentrations were 30-70 times greater in upwelled waters compared to background levels. In the eastern GAB, Richardson et al. (2009) identified water masses during an upwelling event in March 1998 and found nitrate concentrations were higher in upwelled water along the Eyre Peninsula compared to shelf waters, measuring nitrate concentrations up to $5 \mu \mathrm{mol} / \mathrm{L}$. van Ruth et al. (2010b) measured chlorophyll-a and macro nutrient concentrations in coastal waters off southwestern Eyre Peninsula (eastern GAB) during spring, weak upwelling and strong upwelling summers and found that macro nutrients were variable and showed no differences between seasons, despite chlorophyll-a concentrations being an order of magnitude higher during the strong upwelling summer. Finally, a recent analysis by van Ruth et al. (2018) presented nitrate and chlorophyll-a data for the Lincoln Shelf. They found that temperatures $<15^{\circ} \mathrm{C}$ and salinities $<35.6$ were associated with elevated $\mathrm{NO}_{\mathrm{x}}$ concentrations $(>2$ $\mu \mathrm{mol} / \mathrm{L}$ ) and greater primary productivity, and were better indicators of upwelling than wind stress.

To understand and predict phytoplankton blooms in both the Lincoln Shelf and downstream eastern GAB, it is imperative to identify spatial and temporal variability in the chemistry and nutrient enrichment of upwelled water in the Kangaroo Island Pool. This is because: 1) nutrients upwelled onto the shelf drive phytoplankton blooms and overall productivity in the region (van Ruth et al., 2010a), and 2) nutrient concentrations on the shelf are largely controlled by the source depth of upwelled water, as nutrients on the slope increase with increasing depth

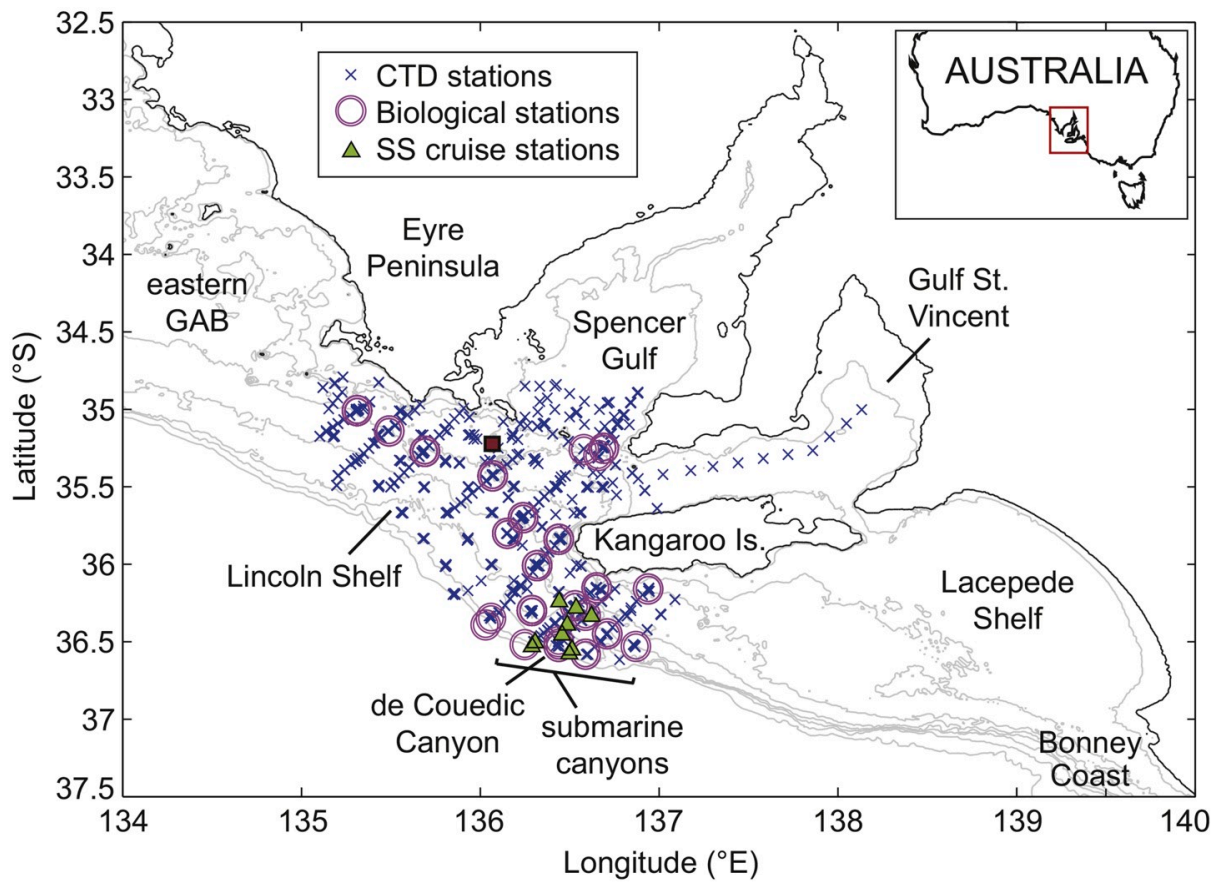

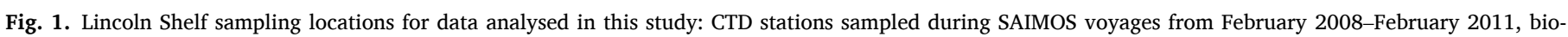

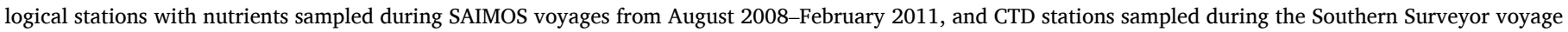
SS2008/02 during February 2008. GAB is Great Australian Bight. Square shows location of the Neptune Island weather station. 
(Richardson et al., 2019). Using water mass analysis techniques: matching the temperature, salinity and nutrient concentrations of upwelled water to the source depth of this water on the slope, we can infer the level of water movement and thus the strength of upwelling. Using data that span three summer seasons, this paper aims to analyse and compare the chemistry of upwelled water on the Lincoln Shelf, identify interannual variability, determine source depth of upwelling for the strongest upwelling events, and compare nutrient enrichment during these events to background levels on the Lincoln Shelf.

\section{Methods}

Hydrographic data and water samples for nutrient analysis were collected aboard the RV Ngerin as part of the Southern Australian Integrated Marine Observing System (SAIMOS; SAIMOS, 2012). 22 research voyages were undertaken on average eight times a year between February 2008 and April 2011 on the Lincoln Shelf between Eyre Peninsula, Kangaroo Island and the mouth of Spencer Gulf, which is an inverse estuary (Fig. 1). Temperature, salinity and pressure data were collected from the surface to within $10 \mathrm{~m}$ of the seafloor using a SeaBird SBE 19+ Conductivity Temperature Depth recorder (CTD) (SeaBird Electronics, Bellevue, Washington, U.S.A.). Not all CTD stations were sampled during each expedition because of weather conditions and the time of year, but CTD and water samples for nutrient analysis were collected routinely at biological stations. Collection of nutrient data began in August 2008. Additional CTD data used in this study are from sampling in de Couedic Canyon (Fig. 1) in February 2008 during Southern Surveyor voyage SS2008/02, accessed from the Commonwealth Scientific and Industrial Research Organisation (CSIRO) databases (CSIRO, 2020).

To analyse and compare surface signals of upwelling events, Sea Surface Temperature (SST) images were accessed from the Integrated Marine Observing System (IMOS) OceanCurrent website (IMOS, 2013). To analyse continental slope properties, hydrographic data for the slope (water depths $150-2000 \mathrm{~m}$ ) for the Lincoln Shelf region $\left(135-137^{\circ} \mathrm{E}\right)$ and Bonney Coast $\left(139-142^{\circ} \mathrm{E}\right)$ were collated from SAIMOS voyages (SAIMOS, 2012), ARGO floats (Coriolis, 2018) and historic hydrographic data stored in the CSIRO databases (CSIRO, 2020).

Water samples were collected for nutrient analysis at biological stations using Niskin bottles at three depths: $15 \mathrm{~m}$, a mid-depth corresponding to the deep chlorophyll maximum (determined using CTD fluorescence), and $\sim 10 \mathrm{~m}$ above the seafloor. A total of 380 samples were analysed for nutrients between August 2008 and February 2011. The majority were from water depths less than $110 \mathrm{~m}$; only 16 were from depths between 120 and $400 \mathrm{~m} .100 \mathrm{ml}$ of each sample was filtered through a bonnet syringe filter $(0.45 \mu \mathrm{m}$ porosity, Micro Analytix Pty Ltd) and stored at $-20^{\circ} \mathrm{C}$ for analysis at SARDI Aquatic Sciences, Adelaide, Australia. Oxides of nitrogen (nitrate + nitrite, $\mathrm{NO}_{\mathrm{x}}$ ), phosphate $\left(\mathrm{PO}_{4}^{3-}\right)$ and silicate $\left(\mathrm{SiO}_{2}\right)$ were determined using Flow Injection
Analysis in a QuickChem QC8500 Automated Ion Analyser (HATCH, 2003; method for nitrate + nitrite: Lachat Quikchem method 31-107-04-1-D, revised 16/09/2003; phosphate: Lachat Quikchem method, 31-115-01-1-G, revised 17/09/2003; and silicate: Lachat Quikchem method 31-114-27-1-A, revised 17/09/2003). Two replicates of each sample were analysed, and results are presented as $\mathrm{NO}_{\mathrm{x}}$ in $\mu \mathrm{mol} / \mathrm{L}$ of $\mathrm{N}$ (detection limit $0.071 \mu \mathrm{mol} / \mathrm{L}$ ), $\mathrm{PO}_{4}$ in $\mu \mathrm{mol} / \mathrm{L}$ of $\mathrm{P}$ (detection limit $0.032 \mu \mathrm{mol} / \mathrm{L}$ ) and $\mathrm{SiO}_{2}$ in $\mu \mathrm{mol} / \mathrm{L}$ (detection limit $0.333 \mu \mathrm{mol} / \mathrm{L})$.

\section{Water mass context}

The upwelling and nutrient characteristics in this study are herein described in the context of Lincoln Shelf water masses previously defined in Richardson et al. (2018). Identification of these water masses was based on hydrographic data and the conservative tracers stable isotopes of oxygen and hydrogen in seawater $\left(\delta^{18} \mathrm{O}\right.$ and $\delta^{2} \mathrm{H}$ ) (see methods in Richardson et al., 2018). Three water masses, Slope Water, Subtropical Surface Water and Evaporated Water, were present year-round on the Lincoln Shelf. Two additional water masses, Mixed Slope Water and Cooled Evaporated Water, are formed by mixing on the shelf, and were only found during summer. A summary of these water masses is presented below, and properties are presented in Table 1. Fig. 2 presents the summer water masses in $\delta^{2} \mathrm{H}$-salinity space, and Fig. 3 shows a schematic of how these water masses are distributed on the Lincoln Shelf.

- Slope Water is a low temperature, low salinity and low stable isotope end member (Table 1; Fig. 2) that is found year-round at depths greater than $180 \mathrm{~m}$. During summer upwelling events, it is transported onto the shelf and can be present at depths as shallow as $40 \mathrm{~m}$. This water mass is sourced from South Australian Basin Central Water, which is formed at the Subtropical Front south of Australia and is transported west along the slope by the Flinders Current System (Richardson et al., 2019).

- Subtropical Surface Water is a mixed shelf water mass with intermediate salinity and stable isotope values that is transported yearround into the region by the eastward flowing South Australian Current. It is well mixed on the shelf down to depths of $180 \mathrm{~m}$ during winter, and is displaced at depth by the inflow of Slope Water during summer upwelling events.

- Evaporated Water is a high salinity and high stable isotope end member that is locally formed at the surface on the inner shelf and within Spencer Gulf from high evaporation and heating during summer. It cools and forms a density current that outflows along the seafloor from Spencer Gulf during winter-spring.

- Mixed Slope Water is a mixed shelf water mass formed by influx of Slope Water onto the shelf during summer upwelling events. Slope Water mixes with Subtropical Surface Water on the shelf to form

Table 1

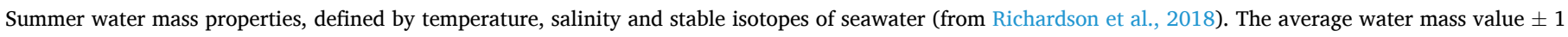
standard deviation is presented for each variable. $\mathrm{n}=$ number of samples. More information is provided in Richardson et al. (2018).

\begin{tabular}{|c|c|c|c|c|c|}
\hline Water mass & $\mathrm{n}$ & Temperature $\left({ }^{\circ} \mathrm{C}\right)$ & Salinity & $\delta^{18} \mathrm{O}(\%)$ & $\delta^{2} \mathrm{H}(\%)$ \\
\hline $\begin{array}{l}\text { Slope Water (SW) } \\
\text { Depth range: } 40-400 \mathrm{~m}\end{array}$ & 52 & $12.7 \pm 1.2$ & $35.21 \pm 0.18$ & $0.12 \pm 0.08$ & $2.0 \pm 0.4$ \\
\hline $\begin{array}{l}\text { Mixed Slope Water (MSW) } \\
\text { Depth range: } 15-120 \mathrm{~m}\end{array}$ & 42 & $15.6 \pm 1.7$ & $35.52 \pm 0.13$ & $0.23 \pm 0.07$ & $2.7 \pm 0.2$ \\
\hline $\begin{array}{l}\text { Subtropical Surface Water (STSW) } \\
\text { Depth range: } 15-120 \mathrm{~m}\end{array}$ & 116 & $17.0 \pm 1.6$ & $35.73 \pm 0.16$ & $0.32 \pm 0.08$ & $3.4 \pm 0.4$ \\
\hline $\begin{array}{l}\text { Evaporated Water (EW) } \\
\text { Depth range: } 15-65 \mathrm{~m}\end{array}$ & 41 & $19.3 \pm 1.0$ & $36.24 \pm 0.41$ & $0.54 \pm 0.14$ & $4.9 \pm 0.8$ \\
\hline $\begin{array}{l}\text { Cooled Evaporated Water (CEW) } \\
\text { Depth range: } 15-105 \mathrm{~m}\end{array}$ & 10 & $15.2 \pm 1.0$ & $35.65 \pm 0.23$ & $0.46 \pm 0.07$ & $4.7 \pm 0.7$ \\
\hline
\end{tabular}




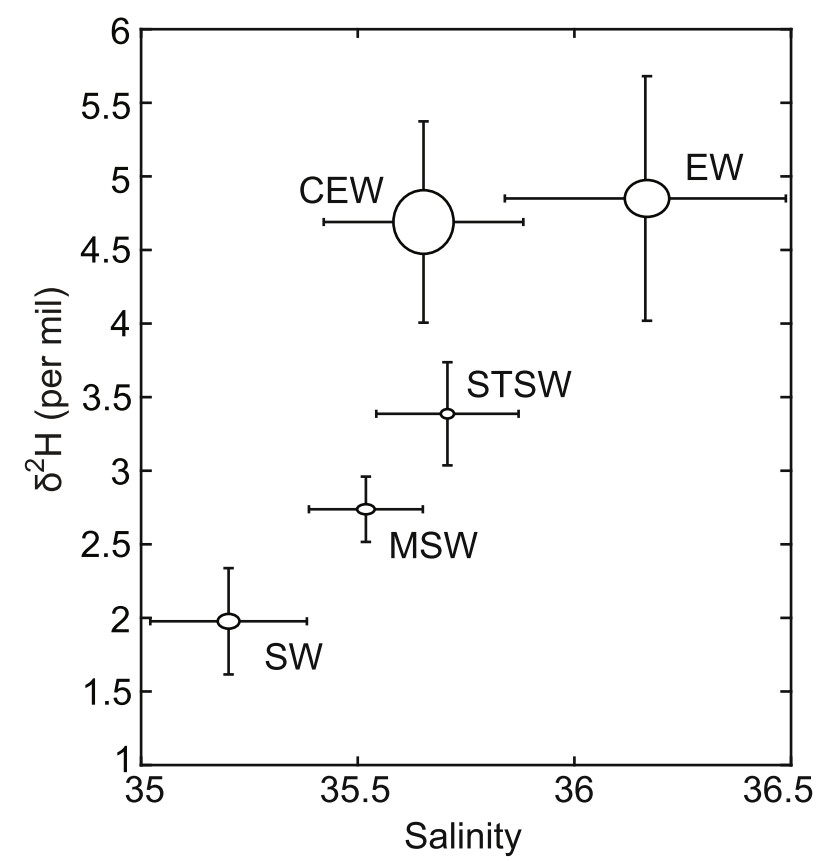

Fig. 2. Means of $\delta^{2} \mathrm{H}$ and salinity for water masses on the Lincoln Shelf during summer. Error bars show 1 standard deviation, and standard error of means are shown by the size and shape of the circles. SW - Slope Water, MSW - Mixed Slope Water, STSW - Subtropical Surface Water, EW - Evaporated Water, CEW - Cooled Evaporated Water. Modified from Richardson et al. (2018).

Mixed Slope Water with intermediate temperature and salinity, and relatively low stable isotope values.

- Cooled Evaporated Water is a mixed shelf water mass with relatively low temperature and salinity but high stable isotope values. It is formed by vertical mixing of surface Evaporated Water with low temperature and salinity bottom water during summer, and retains the high isotopic signature of Evaporated Water. It is found close to the seafloor, predominantly during summer months with no upwelling.

\section{Results}

\subsection{Upwelling characteristics}

During winter-spring, from May to October, shelf waters were well mixed down to at least $150 \mathrm{~m}$. During summer-autumn, from November to April, a seasonal thermocline developed and waters were stratified, with a surface mixed layer $\sim 40 \mathrm{~m}$ (see Fig. 4 in Richardson et al., 2018). At depth, properties were cooler and fresher in summer, and warmer and more saline in winter (Fig. 4). Even during the 2008/2009 summer, when there was minimal upwelling, summer salinities at depth were lower than during winter, a result of a raised thermocline bringing lower salinity water onto the shelf. During summer, average monthly surface temperatures and salinities did not vary significantly between years, whereas average monthly bottom temperatures and salinities were lowest in early 2008 and the 2009/2010 summer (Fig. 4).

The temperature versus salinity plot of all hydrographic samples shows four end members (Fig. 5a). In the context of shelf water masses described above, these end members relate to upwelled Slope Water (cool, fresh), Mixed Slope Water (warm, fresh), summer Evaporated Water (warm, saline) and winter Evaporated Water (cool, saline).

Upwelling events in the region can occur several times during the summer-autumn season. On the Lincoln Shelf, the temperature and salinity (T/S) signature of upwelled water was $<13.5^{\circ} \mathrm{C}$ and $<35.3$, in which the water had a linear T/S relationship (Fig. 5a). As the water upwelled onto the shelf and mixed with shelf water, the linear relationship changed to a triangular relationship, spreading between warm, fresh (MSW) and warm, saline (EW) end members (Fig. 5a). A strong upwelling event was characterised by cool, fresh Slope Water with temperature and salinity less than $12.5^{\circ} \mathrm{C}$ and 35.2 on the shelf. These water properties were present in February and March 2008, and February and March 2010. These months also had the lowest average

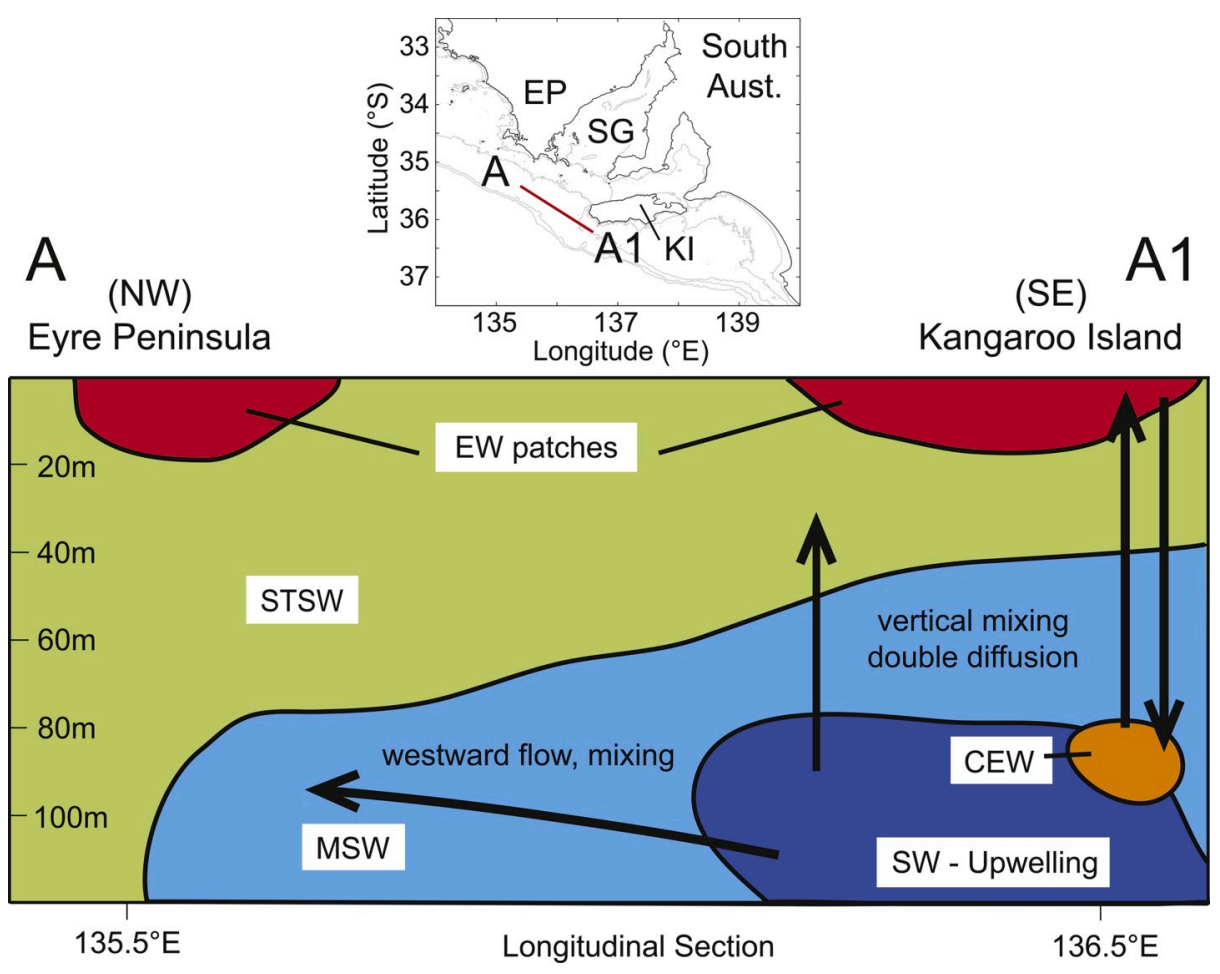

Fig. 3. Schematic of summer water masses on the Lincoln Shelf, for section A-A1 (see top inset for location). Slope Water (SW) upwells and mixes with Subtropical Surface Water (STSW) to form Mixed Slope Water (MSW) as it flows west and mixes vertically on the shelf. Patches of Evaporated Water (EW) form at the surface from surface heating and evaporation, and vertical mixing processes mix this EW with bottom waters to form Cooled Evaporated Water (CEW). From Richardson et al. (2018). 


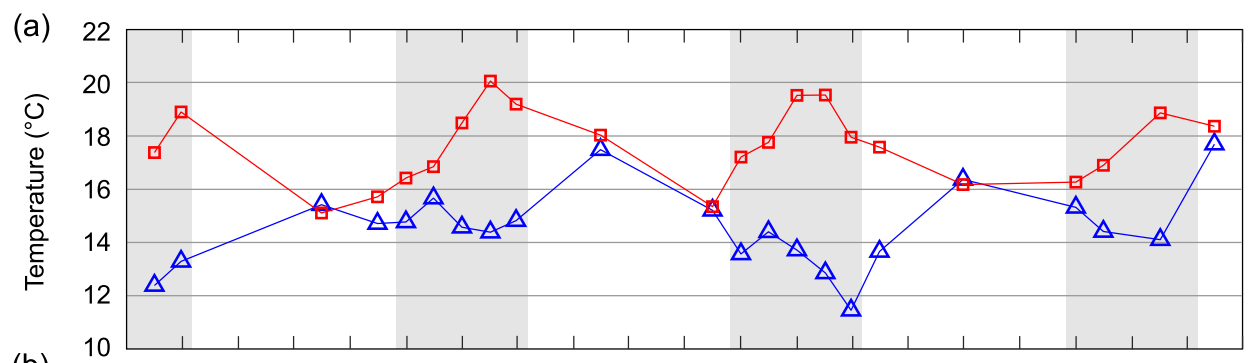

(b)

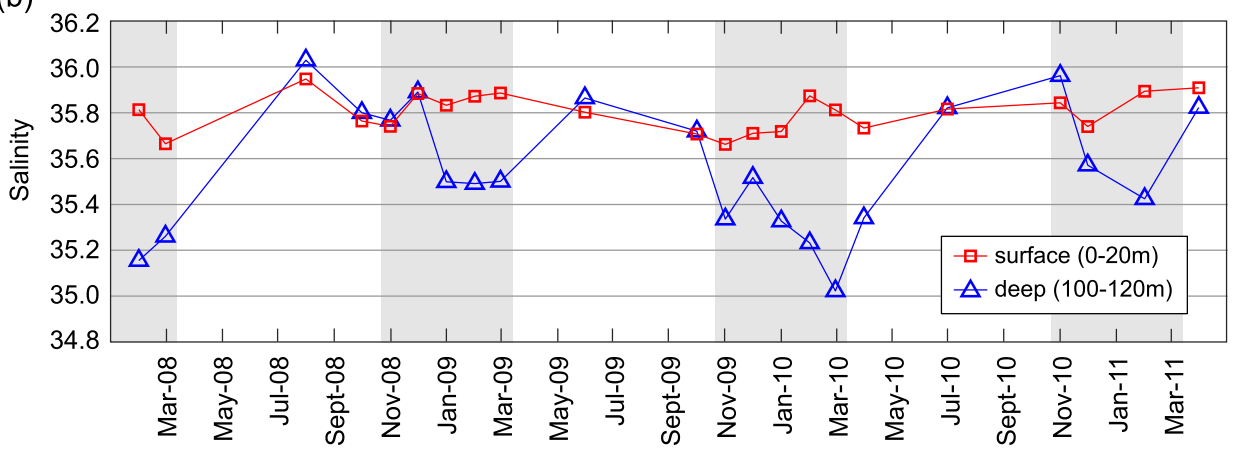

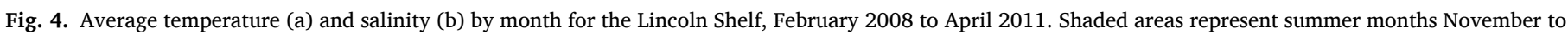
March, where the water column is stratified and there is a divergence of surface and deep water properties.
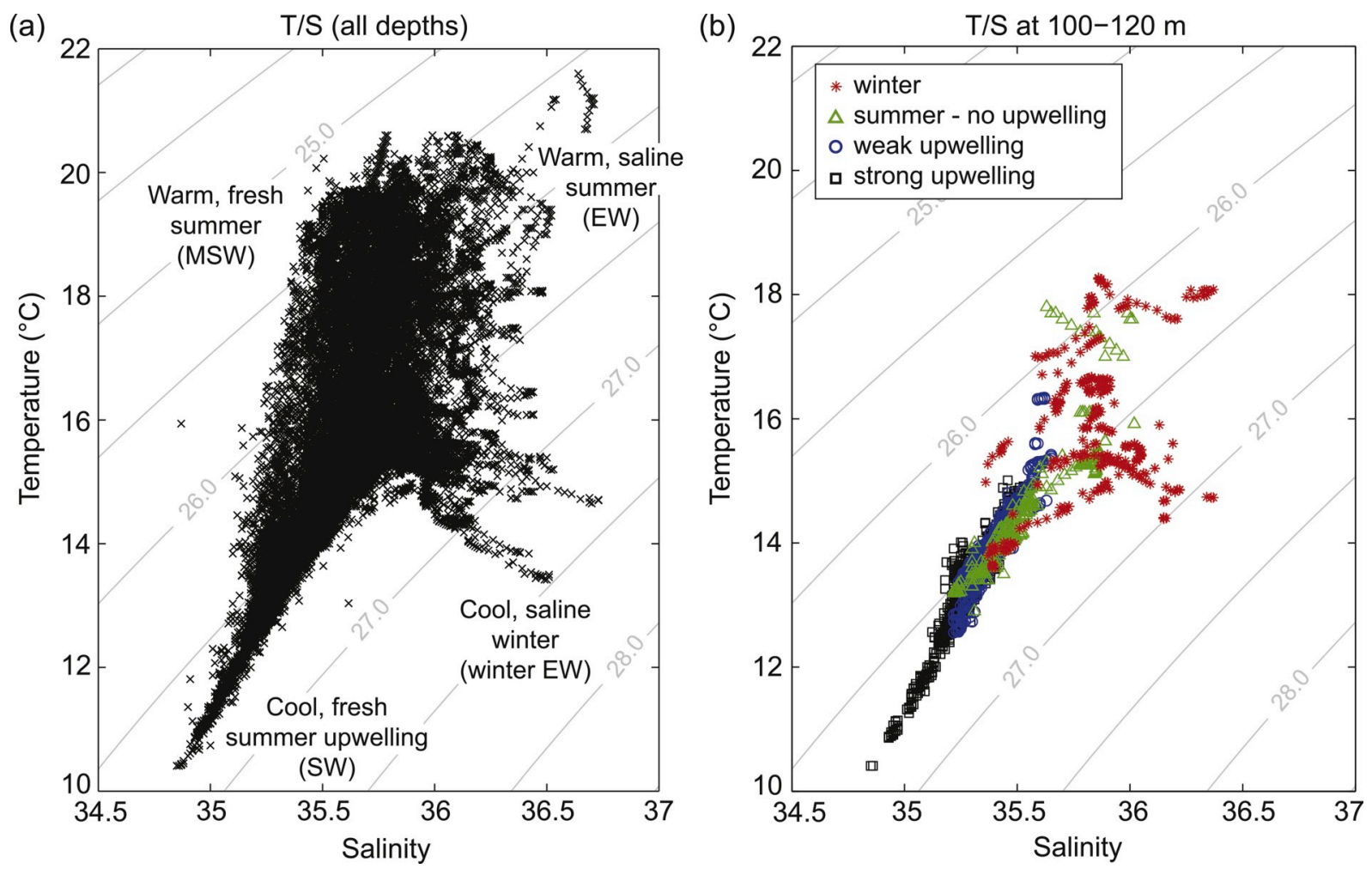

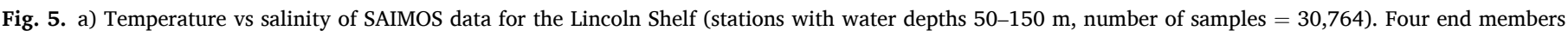

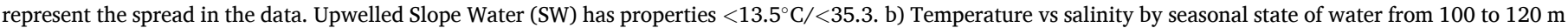

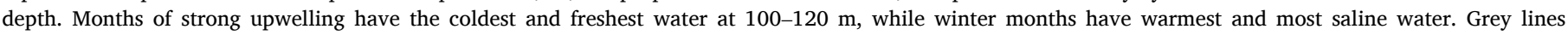
denote density.

temperature and salinity at $100-120 \mathrm{~m}$ for the study period (Fig. 4).

Once upwelled, Slope Water was recognised on the shelf by its low isotopic signature, even though initial mixing with Subtropical Surface Water could increase temperatures and salinities to $15^{\circ} \mathrm{C}$ and 35.55 (Table 1; Richardson et al., 2018). Nutrient-rich Slope Water was present during all four summers sampled, but was not present before
January, and was more prevalent later in the summer, from February onwards.

Between 2008 and 2011, four monthly states were identified in the region based on the season, distribution of water masses, and level of nutrient enrichment on the shelf. These characteristics are herein used to infer the intensity of upwelling events, as lower temperature, lower 
(a)

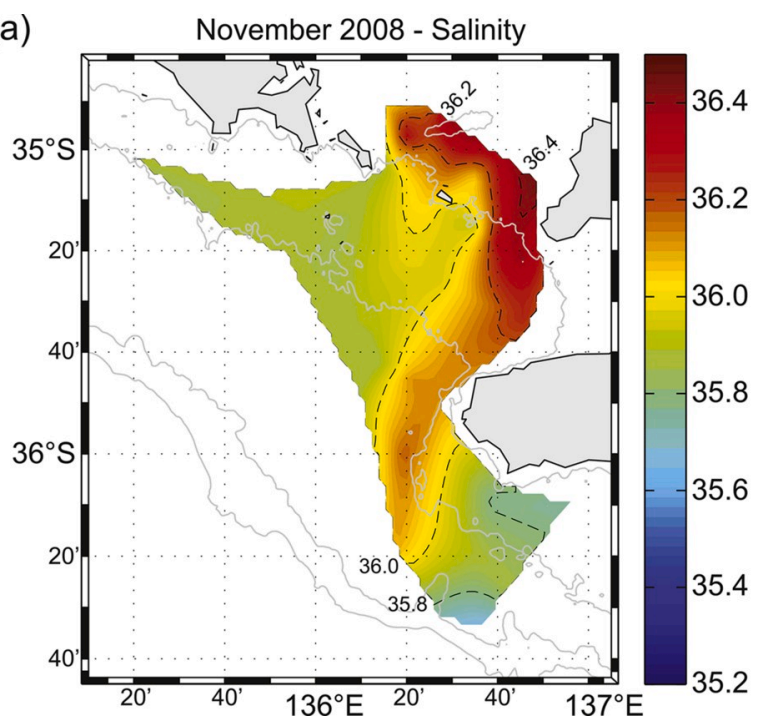

(b)

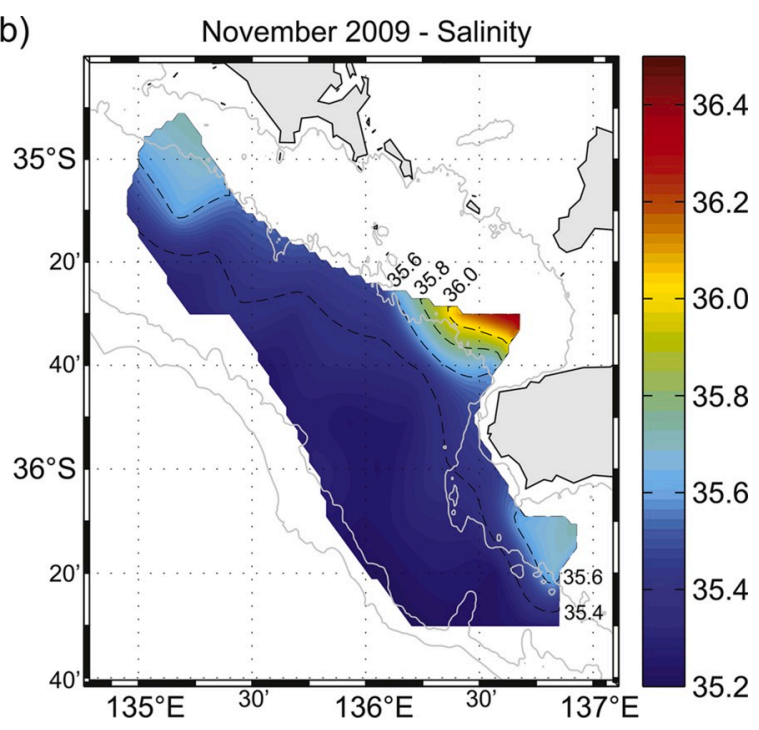

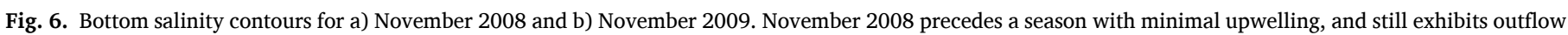

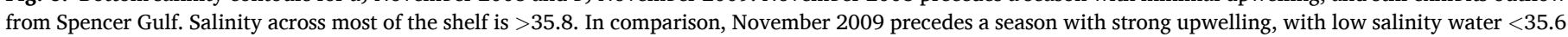
present across most of the shelf at depth.

salinity and higher nutrient water must be sourced from deeper on the slope, based on slope properties (Richardson et al., 2019). These four states are:

1) Winter months (May to October), with Subtropical Surface Water widespread on the shelf;

2) Summer months (December to April) with no upwelling, where $13.5^{\circ} \mathrm{C} / 35.3$ Slope Water was present at the shelf edge at depths $>120 \mathrm{~m}$, but Subtropical Surface Water was dominant on the shelf;

3) Summer months with weak upwelling, where Mixed Slope Water was widespread on the shelf at depth, implying influx and mixing of Slope Water; and,

4) Summer months with strong upwelling, where Slope Water with $T / S$ of $12.5 / 35.2$ was widespread on the shelf at depth.

$\mathrm{T} / \mathrm{S}$ characteristics of water from 100 to $120 \mathrm{~m}$ show the distinction between each seasonal state, especially the cool and fresh water present only during months of strong upwelling (Fig. 5b). November was a transition month and had summer conditions when preceding a strong upwelling season, such as November 2009, and had winter conditions when preceding a season of minimal upwelling, such as November 2008 and November 2010. Average temperatures and salinities for November 2008, 2009 and 2010 (Fig. 4), as well as bottom salinity contours for November 2008 and 2009 (Fig. 6), highlight the differences between these two situations.

Summer months with no upwelling had Subtropical Surface Water across the shelf. Such was the case for January, February, November and December 2009, and December 2010. The 2008-2009 summer season had very little upwelled water present on the shelf. Only late in the season, during March 2009, was there significant Mixed Slope Water present at depth, indicating a month of weak upwelling. Other months of weak upwelling included January and April 2010, and February 2011. Summer months with strong upwelling had Slope Water with T/S of $12.5^{\circ} \mathrm{C} / 35.2$ widespread on the shelf at depth (Fig. 5b), and these included February and March 2008, and February and March 2010.

Of the four strong upwelling months, coldest temperatures and lowest salinities occurred during March $2010\left(10.4^{\circ} \mathrm{C} / 34.85\right.$ at $\left.105 \mathrm{~m}\right)$ and February $2008\left(10.67^{\circ} \mathrm{C} / 34.9\right.$ at $\left.90 \mathrm{~m}\right)$, followed by February 2010 $\left(11.3^{\circ} \mathrm{C} / 35.01\right.$ at $\left.130 \mathrm{~m}\right)$ and March $2008\left(12.38^{\circ} \mathrm{C} / 35.16\right.$ at $\left.124 \mathrm{~m}\right)$ (Table 2). An $R V$ Southern Surveyor voyage a few days after the February 2008 SAIMOS voyage also sampled very low temperature and salinity water, of $10.3^{\circ} \mathrm{C} / 34.85$ at $100 \mathrm{~m}$, in the same region (Fig. 1). These temperatures and salinities were considerably less than those present at depth during non-upwelling months (Fig. 5b). Temperature and salinity at the base of the seasonal thermocline for strong upwelling months was less than $12.5^{\circ} \mathrm{C} / 35.15$ (Table 2), while it was $>14^{\circ} \mathrm{C}$ / $>35.4$ during non-upwelling months. Differences can be clearly seen in depth profiles from February and March for the three summer seasons (Fig. 7).

Off-shelf profiles were highly variable both within and between months, depending on the location along the shelf and to what extent the thermocline rose during upwelling events (e.g., Fig. 7). For example,

Table 2

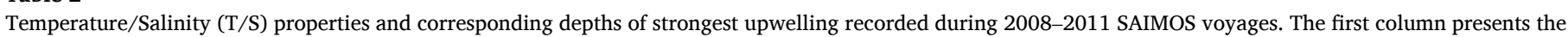

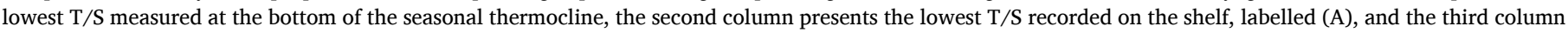

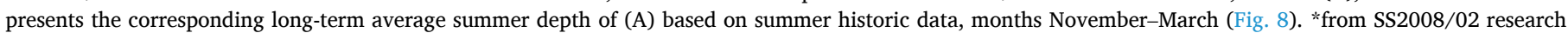
voyage, $136.5^{\circ} \mathrm{E}, 17$ th-21st February 2008 .

\begin{tabular}{|c|c|c|c|}
\hline Month & $\begin{array}{l}\text { Lowest } \mathrm{T} / \mathrm{S} \text { at bottom } \\
\text { of seasonal thermocline }\end{array}$ & $\begin{array}{l}\text { Lowest } \mathrm{T} / \mathrm{S} \text { recorded } \\
\text { on the shelf }(\mathrm{A})\end{array}$ & $\begin{array}{l}\text { Summer average } \\
\text { depth at } 136^{\circ} \mathrm{E} \\
\text { (historic) of (A) }\end{array}$ \\
\hline \multirow[t]{2}{*}{ February 2008} & $11.5^{\circ} \mathrm{C} / 35.0$ at $65 \mathrm{~m}$ & $10.67^{\circ} \mathrm{C} / 34.9$ at $90 \mathrm{~m}$ & $350 \mathrm{~m}$ \\
\hline & & $10.3^{\circ} \mathrm{C} / 34.85$ at $100 \mathrm{~m}^{*}$ & $370 \mathrm{~m}$ \\
\hline March 2008 & $12.5^{\circ} \mathrm{C} / 35.15$ at $50 \mathrm{~m}$ & $12.38^{\circ} \mathrm{C} / 35.15$ at $124 \mathrm{~m}$ & $240 \mathrm{~m}$ \\
\hline February 2010 & $12.4^{\circ} \mathrm{C} / 35.15$ at $55 \mathrm{~m}$ & $11.3^{\circ} \mathrm{C} / 35.0$ at $130 \mathrm{~m}$ & $300 \mathrm{~m}$ \\
\hline March 2010 & $11.13^{\circ} \mathrm{C} / 35.0$ at $55 \mathrm{~m}$ & $10.4^{\circ} \mathrm{C} / 34.85$ at $105 \mathrm{~m}$ & $370 \mathrm{~m}$ \\
\hline
\end{tabular}


(a) February-March temperature profiles

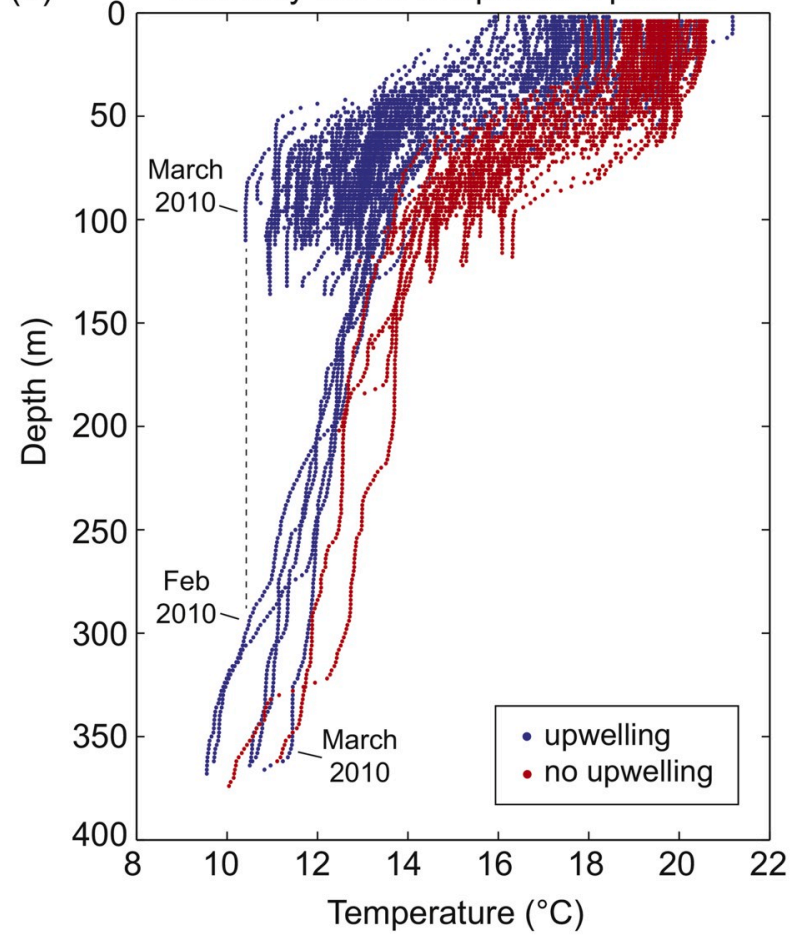

(b)

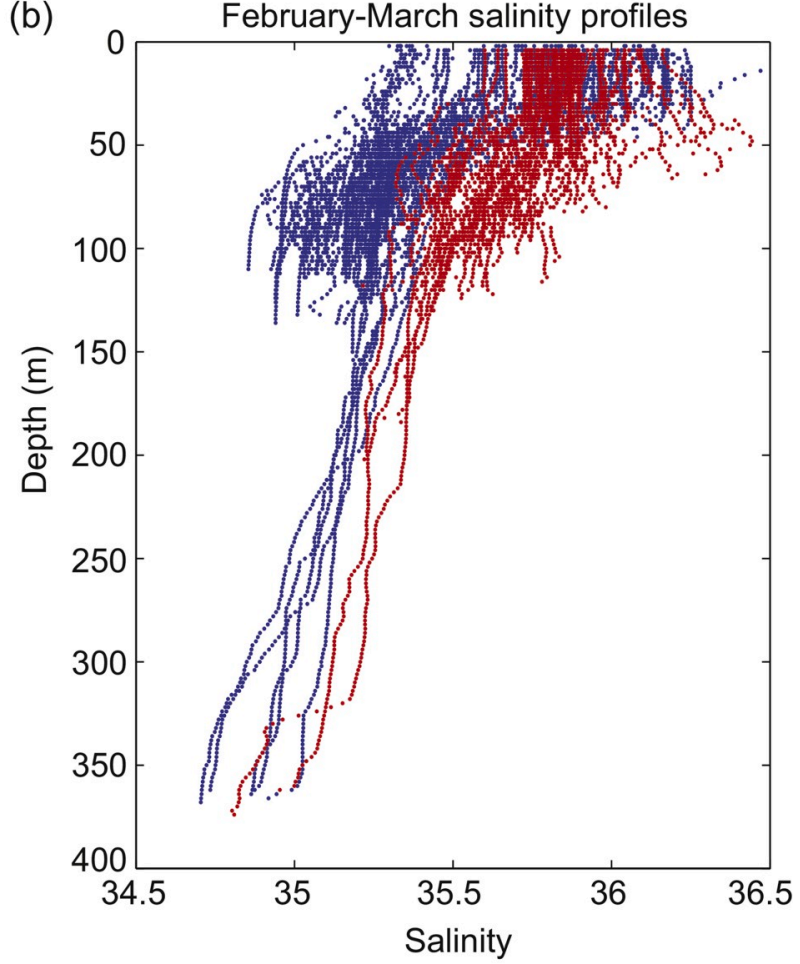

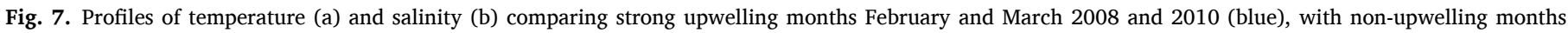
February and March 2009 (red). (For interpretation of the references to colour in this figure legend, the reader is referred to the Web version of this article.)

(a)

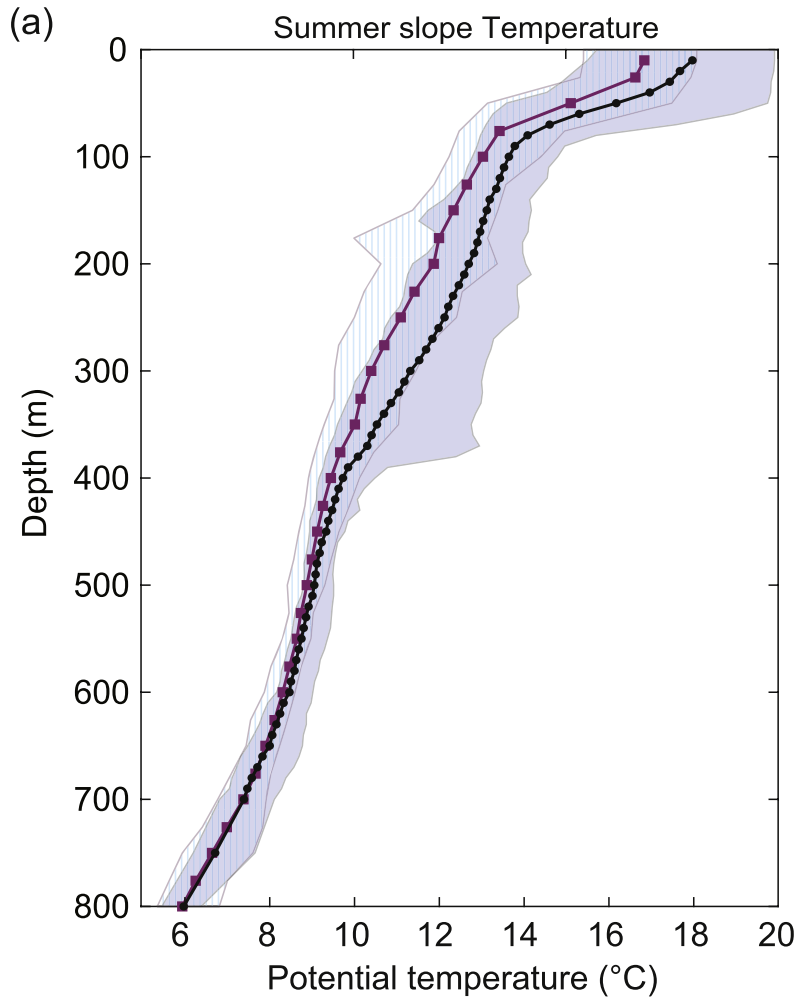

(b)

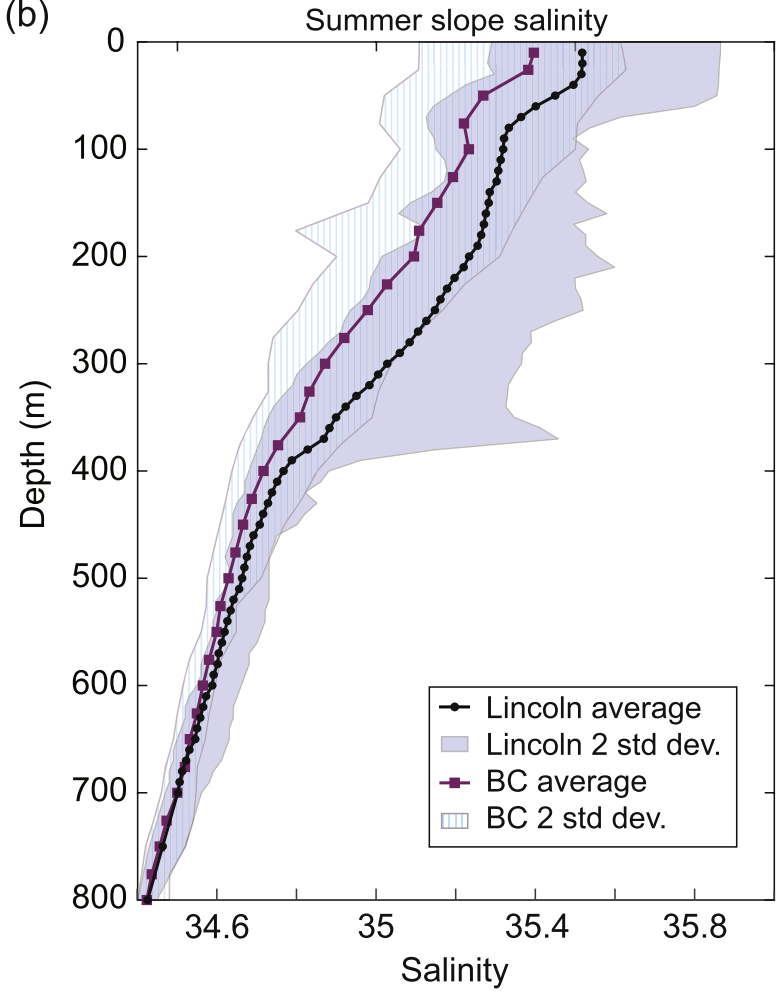

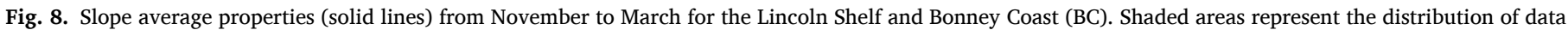

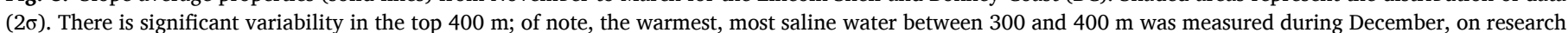
cruises in 1994 and 2015, showing that outflow from Spencer Gulf can still be influencing the slope in early summer. 
four slope profiles sampled on the same day in February 2010, between 135.8 and $136.5^{\circ} \mathrm{E}$, vary in temperature by $1^{\circ} \mathrm{C}$ at $360 \mathrm{~m}$ (Fig. 7). Of these four profiles, the two to the west showed lower temperature and salinity water shallower in the water column, suggesting isotherms were raised due to upwelling. Such variability is poorly understood, and makes it difficult to assign a source depth of upwelled water. However, averaging the available summer historic data (November to March) for the slope (Fig. 8), can help estimate a source depth for each strong upwelling month, and these estimates are presented in Table 2 . The difference of $1^{\circ} \mathrm{C}$ in the February 2010 profiles represents a depth difference of $70-80 \mathrm{~m}$ in average slope data, indicating the extent to which isotherms can be raised between upwelling and non-upwelling conditions.

Off-shelf profiles in the east of the study area, south of Kangaroo Island, consistently showed shallower isotherms than areas to the west, closer to Eyre Peninsula. In addition, isotherms further east along the Bonney Coast $\left(139-142^{\circ} \mathrm{E}\right)$, are on average raised by $60-75 \mathrm{~m}$ more than those of the Lincoln Shelf $\left(\sim 135-137^{\circ} \mathrm{E}\right)$ (Fig. 8). This has also been observed in earlier studies (Middleton et al., 2007; Middleton and Bye, 2007).

Averaged summer and winter wind stress data for 2008-2010 shows that the 2008 summer had the most upwelling favourable conditions (Fig. 9). Weekly averaged data, however, shows significant variation (Fig. 10). An early summer peak in wind stress is observed during both November 2007 and 2009, but is absent during November 2008. The 2009-2010 summer season had variable winds, with a drop in wind stress over December and January, and an increase in February. Peaks in wind stress correlate well with three of the four months of strong upwelling observed in the study period (dashed lines in Fig. 10). A very large peak in wind stress during March 2010 correlates with the strongest upwelling event recorded during this study. Event-scale wind stress could be a better indicator of upwelling events than monthly averaged wind stress.

\subsubsection{8 upwelling season}

SAIMOS voyages sampled upwelled water from the 12th-14th February 2008 and again from the 15th-17th March 2008. SST images show that several strong upwelling events occurred between the Eyre Peninsula $\left(135^{\circ} \mathrm{E}\right)$ and the Bonney Coast $\left(\sim 140^{\circ} \mathrm{E}\right)$ from January to

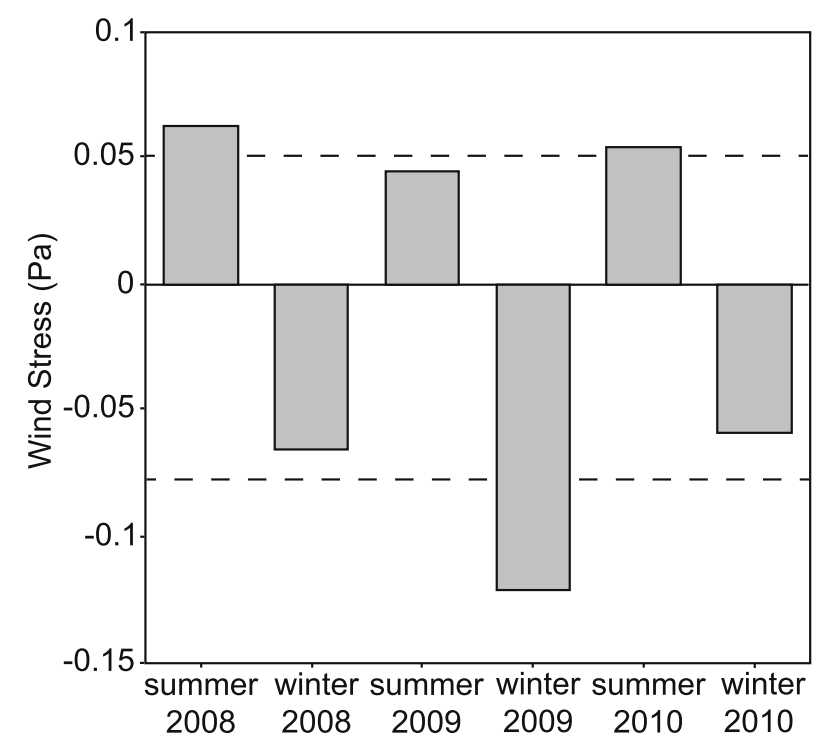

Fig. 9. Mean wind stress for Neptune Island, South Australia (see location in Fig. 1), calculated for summer (January-March) and winter (June-September). Positive values indicate upwelling favourable conditions and negative values indicate downwelling favourable conditions (SE-NW grid). Dashed lines represent the long-term summer and winter means.

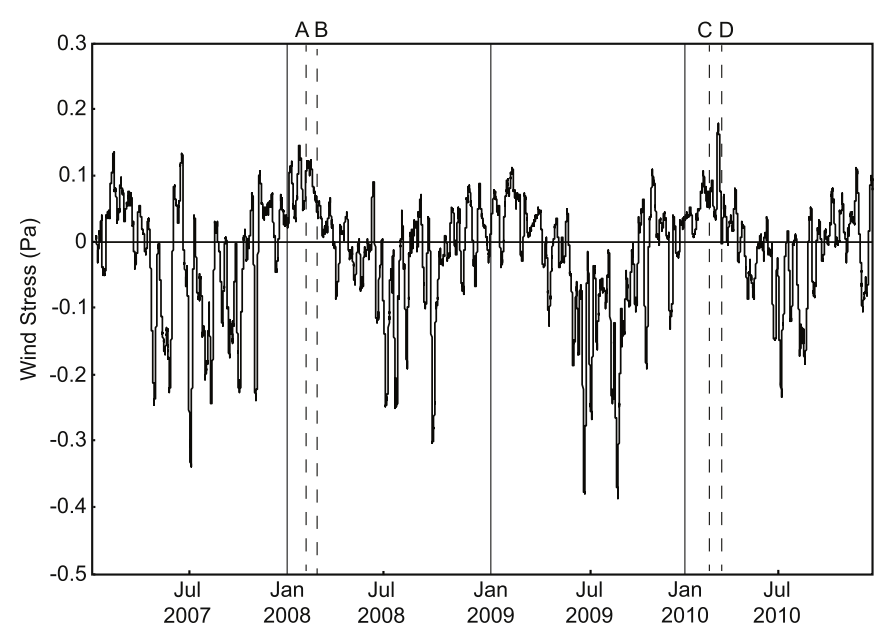

Fig. 10. Weekly averaged wind stress for Neptune Island for the period January 2007-December 2010. Positive values represent upwelling favourable conditions. Dashed lines indicate strong upwelling events in February and March 2008 (A and B) and February and March 2010 (C and D).

March. The upwelling event sampled on the February voyage began on the 30th January, with cold, $15^{\circ} \mathrm{C}$ surface water along the Bonney Coast, with small surface signals off the western tip of Kangaroo Island and off western Eyre Peninsula. By the 5th February the Bonney Coast cold plume had spread to the south of Kangaroo Island, but the Kangaroo Island signal remained small. On the 13th and 14th February this signal grew to its largest extent (Fig. 11). This upwelling peak encompassed all three upwelling centres - the Bonney Coast cold plume had spread as far as southwest of Kangaroo Island, and upwelled water was present along western Eyre Peninsula. The timing of the February voyage captured this event.

During the February 2008 voyage, coldest and freshest water sampled at the bottom of the seasonal thermocline at $\sim 60 \mathrm{~m}$ was $\sim 11.5^{\circ} \mathrm{C}$ and 35.0. This water was not present at the shelf edge but close to the western tip of Kangaroo Island. Bottom contours of temperature and salinity illustrate the location of this cold water, with warmer and more saline water closer to the shelf edge (Fig. 12a and b). This cold plume appears to be coming from the east, in agreement with the SST images that show the Bonney Coast upwelling plume spreading towards Kangaroo Island (Fig. 11).

The source of upwelled water onto the shelf is not as clear in bottom temperature and salinity contours from March 2008 (Fig. 12c and d). Warmer and more saline water adjacent to de Couedic Canyon suggests that upwelling was not coming up through this major submarine canyon. The coldest water was still, however, situated off southwestern Kangaroo Island, as part of the Kangaroo Island Pool.

The coldest and freshest shelf water sampled during March, of $12.38^{\circ} \mathrm{C} / 35.15$ at $124 \mathrm{~m}$, was not present in the off-shelf profile sampled to $380 \mathrm{~m}$. The off-shelf profile did not have the raised isotherms that are observed during an upwelling event, suggesting that the upwelling event had passed. Therefore, based on these properties and the SST images, it is likely that shelf water measured on the March voyage was upwelled at an earlier time.

\subsubsection{0 upwelling season}

The strong upwelling season of 2009-2010 started in November 2009. There was a drop of $1.5^{\circ} \mathrm{C}$ in temperature at $100-120 \mathrm{~m}$ between October and November 2009 (Fig. 4a), and average salinities were as low as 35.3 in November 2009 (Fig. 4b), signalling the onset of the upwelling season. During the 2008-2009 summer season, by comparison, average salinities at 100-120 m in November and December 2008 were greater than 35.8 (Figs. 4b and 6), before salinity dropped to only 35.5 in January-March 2009. Therefore, for the strong upwelling season 


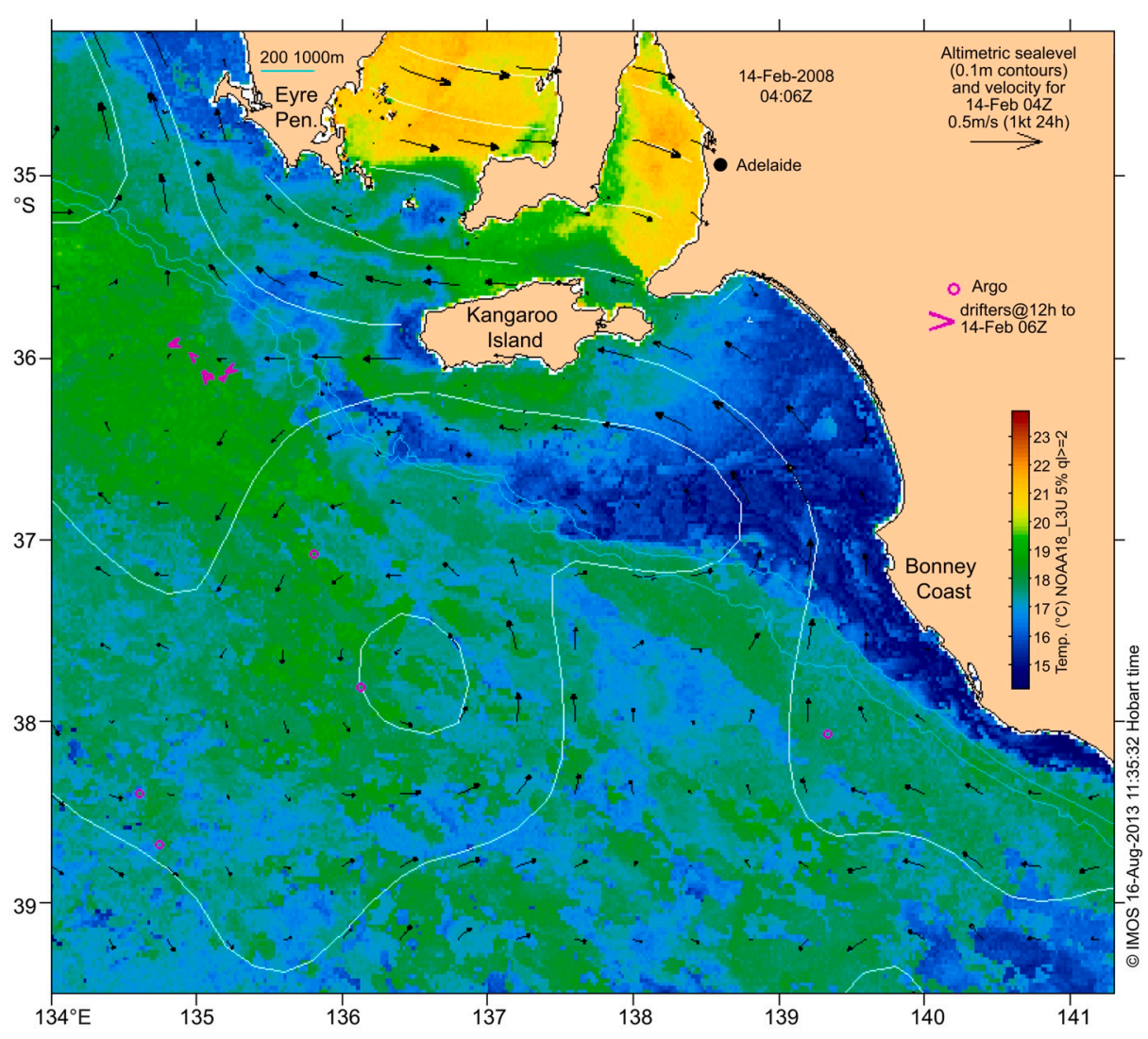

Fig. 11. Sea Surface Temperature (SST) image of a strong upwelling event on the $14^{\text {th }}$ February 2008. Consecutive upwelling occurs along the Bonney Coast (east), the western tip of Kangaroo Island and along the western Eyre Peninsula (Eyre Pen., west). Upwelling along the Bonney Coast is most predominant and spreads towards Kangaroo Island. Source: IMOS OceanCurrent (IMOS, 2013).

of 2009-2010, upwelling began in November and strengthened in February and March. Despite the low temperature and salinity in November 2009, no nutrient enrichment was observed until later in the summer.

SST images (e.g., Fig. 13) show consistently cold $\left(\sim 15^{\circ} \mathrm{C}\right)$ water along the Bonney Coast during February and March 2010. Cold surface water was also present along the western Eyre Peninsula between the 28th February and 19th March. A surface signal off the western tip of Kangaroo Island was not as prevalent however, with $15-16^{\circ} \mathrm{C}$ water only present during 3-5th March and the 12-13th March. The Bonney Coast upwelling was at its greatest spatial extent during these times, spreading along the shelf edge south of Kangaroo Island (Fig. 13). The strong 12-13th March upwelling event was sampled during the 16-18th March voyage, recording the lowest temperatures and salinities on the shelf during the study period, of $10.4^{\circ} \mathrm{C} / 34.85$ at $105 \mathrm{~m}$ to the southwest of Kangaroo Island and just west of de Couedic Canyon $\left(36.3^{\circ} \mathrm{S} / 136.3^{\circ} \mathrm{E}\right.$; cross in Fig. 14c).

Extensive sampling during the 16-18th February 2010 voyage resulted in good spatial coverage of data on the shelf. Bottom temperature and salinity contours show cooler and less saline water as a pool in the center of the Lincoln shelf, to the west of Kangaroo Island, with a path to the shelf edge at around $136^{\circ} 20^{\prime} \mathrm{E}$ (Fig. 14a and b). This water appears to be coming directly from the shelf edge, possibly from de Couedic Canyon to the south of Kangaroo Island. Sampling close to the shelf edge during the 16-18th March 2010 voyage was limited and focused around de Couedic Canyon, showing that slope waters could be coming through this canyon (Fig. 14c and d), and water properties to the east of the canyon, down to $136 \mathrm{~m}$, had higher temperature and salinity, and lower nutrients, than waters west of the canyon.

During the March 2010 voyage, very cool and fresh water, less than $12^{\circ} \mathrm{C}$ and 35.1 , was present in depths as shallow as $40 \mathrm{~m}$ southwest of
Kangaroo Island (Fig. 7). Mixed Slope Water was also present at the surface, indicating mixing of surface waters with the upwelled water mass (Richardson et al., 2018). The March 2010 slope profile, sampled to $365 \mathrm{~m}$ (Fig. 7), was warmer and more saline than the coldest and freshest water recorded on the shelf $\left(10.4^{\circ} \mathrm{C} / 34.85\right)$. Like during March 2008 , the off-shelf profile suggests that the upwelling event had passed. However, water with these cold, fresh characteristics was detected in the two upwelling profiles sampled during February 2010, at 300 and $306 \mathrm{~m}$ (Fig. 7). This deep water sampled in February 2010 could be the same water found on the shelf during March 2010. Water upwelled during February along the Bonney Coast could also have been transported west and upwelled in the Kangaroo Island upwelling pool during March. As concluded by Richardson et al. (2018) using the same temperature and salinity data, this situation would indicate that the strong upwelling event during March 2010 was sourced from $\sim 300 \mathrm{~m}$. The average depth of this water in historic slope profiles (Fig. 8; Table 2) is $370 \mathrm{~m}$, therefore it appears that isotherms can be raised significantly during upwelling events, and upwelled water is sourced from substantial depths.

\subsection{Nutrients and upwelling}

Identifying nutrient characteristics by season and upwelling state is useful to determine average shelf nutrient values during upwelling events, for future predictions of nutrient inputs to the shelf. Average shelf values of nutrients for each seasonal state are presented in Table 3. $\mathrm{Si}^{*}$ is the relative abundance of silicate to nitrate, and has been used as a conservative tracer of Southern Ocean water masses (Sarmiento et al., 2004). In this case $\mathrm{Si}^{*}=\left[\mathrm{SiO}_{2}-\mathrm{NO}_{\mathrm{x}}\right]$, measured in $\mu \mathrm{mol} / \mathrm{L}$. Sarmiento et al. (2004) used nitrate instead of $\mathrm{NO}_{\mathrm{x}}$, however it is herein proposed that $\mathrm{NO}_{\mathrm{x}}$ is an acceptable substitution because nitrite is a small fraction of $\mathrm{NO}_{\mathrm{x}}$ in shelf waters (global average 1.4\%) and is insignificant in water 
(a)

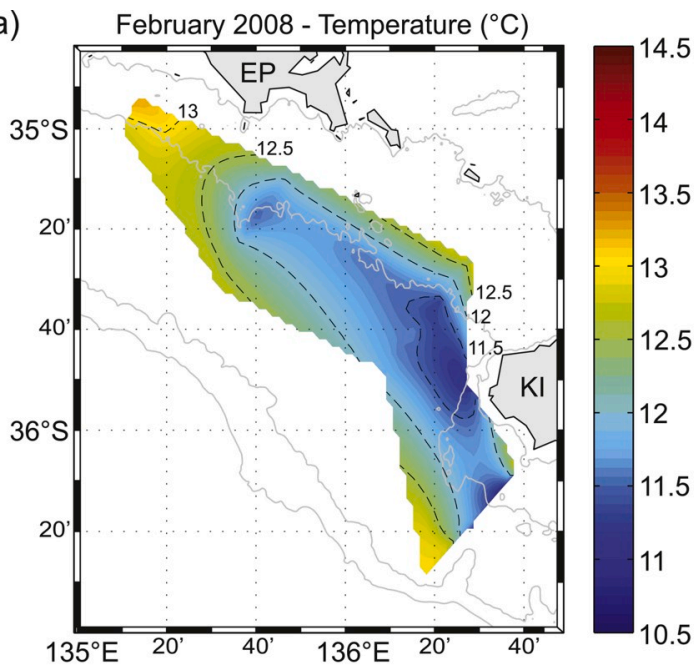

(c)

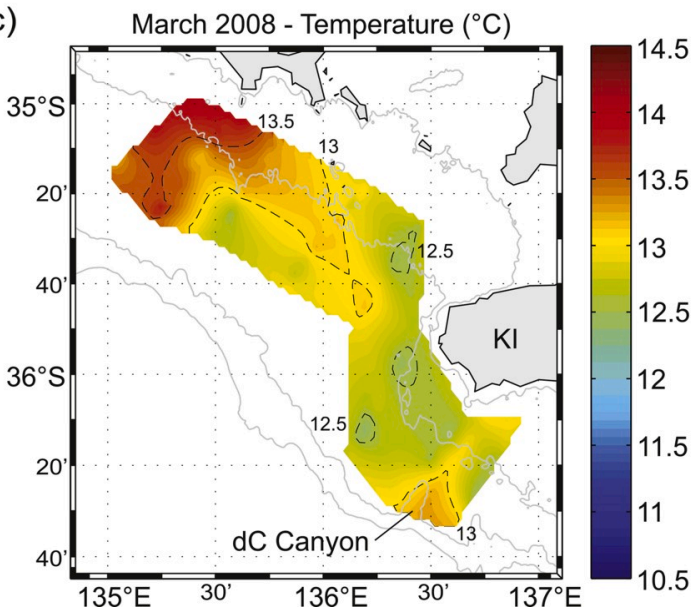

(b)

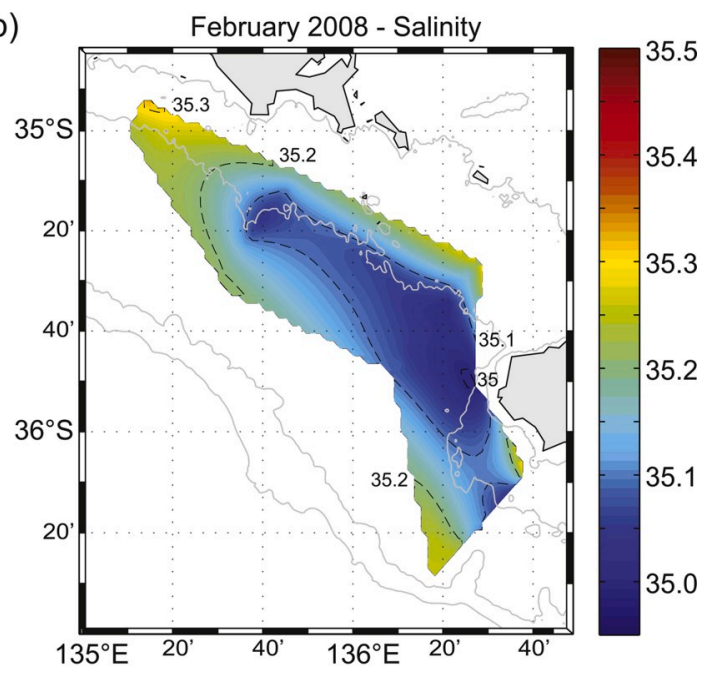

(d)

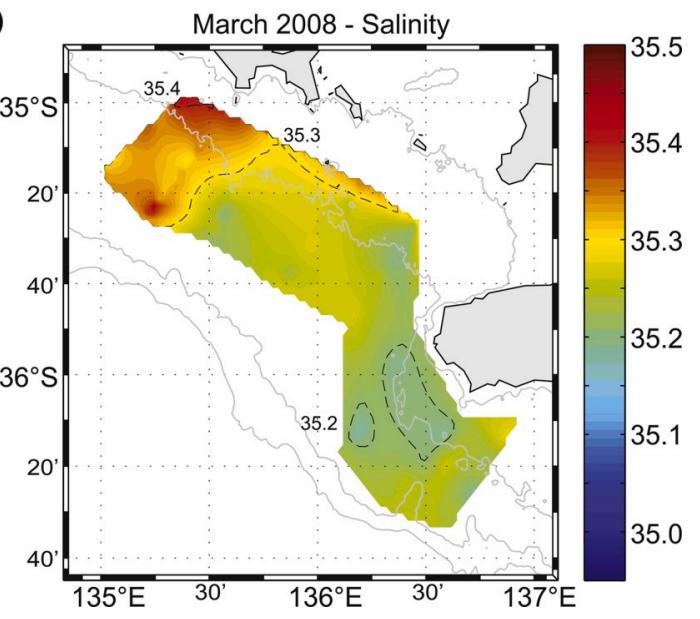

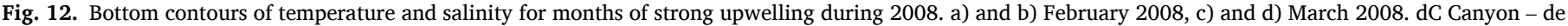
Couedic Canyon.

below the photic zone (global average $0.02 \%$ ) (Gruber, 2008). Nutrient data collection commenced in August 2008, therefore nutrient characteristics of strong upwelling events presented here are from data collected during February and March 2010. Samples from April 2010, while not having water less than $13.5^{\circ} \mathrm{C}$ and 35.3 , recorded high nutrient concentrations and low stable isotope values, likely due to remnant upwelled water from March 2010; therefore, April 2010 is included in this section as a strong upwelling month.

\subsubsection{Nutrient relationships}

$\mathrm{NO}_{\mathrm{x}}$ and phosphate data show a positive linear relationship for the Lincoln Shelf (Fig. 15), with a slope fit of $13.3 \mathrm{x}-0.10$ and $\mathrm{R}^{2}=0.87$. The average $\mathrm{NO}_{\mathrm{x}}$ :phosphate ratio was $11: 1$, which is lower than the average Redfield molar ratio found by Martiny et al. (2013) between 30 and $40^{\circ} \mathrm{S}$, of $16: 1$, but is similar to the average ratio of $12: 1$ found at $50^{\circ} \mathrm{S}$. Water at the shelf break and on the upper slope $(120-350 \mathrm{~m})$ during strong upwelling months had an average ratio of $16: 1$, but on the shelf the average ratio was 11.3:1, suggesting faster uptake of $\mathrm{NO}_{\mathrm{x}}$ than phosphate when nutrients are brought onto the shelf and into the euphotic zone. The lowest average shelf ratio of 8:1 occurred during weak upwelling months, suggesting $\mathrm{NO}_{\mathrm{x}}$ is quickly utilized when small to moderate nutrient inputs occur. These results indicate that $\mathrm{NO}_{\mathrm{x}}$ is limited relative to phosphate on the shelf. Strong upwelling months exhibited robust linear relationships between $\mathrm{NO}_{\mathrm{x}}$ and phosphate; the relationship in March 2010 had an $\mathrm{R}^{2}$ of 0.99 , whereas February 2010 and April 2010 had $\mathrm{R}^{2}$ values of 0.95 and 0.91 , respectively. In comparison, there was almost no relationship between the two nutrients during wintertime, with $\mathrm{R}^{2}$ values around 0.12 .

The relationship between $\mathrm{NO}_{\mathrm{x}}$ and phosphate during strong upwelling months is related to the strong linear relationships in water masses on the slope, between temperature, salinity, $\mathrm{NO}_{\mathrm{x}}$ and phosphate (Richardson et al., 2019). Strong relationships between temperature and $\mathrm{NO}_{\mathrm{x}}$, and temperature and phosphate are present in slope waters along the southern Australian margin (150-2000 m water depth, $115-145^{\circ} \mathrm{E}$; CSIRO, 2020) (Fig. 16), and these relationships are retained at bottom depths on the shelf during strong upwelling months (squares in Fig. 16). This was especially true for $\mathrm{NO}_{\mathrm{x}}$ when temperatures were $<13^{\circ} \mathrm{C}$, and for phosphate when temperatures were $<12^{\circ} \mathrm{C}$. As upwelled bottom waters flowed north and west, towards Spencer Gulf and Eyre Peninsula, temperatures increased but nutrients remained elevated below the euphotic zone. This was the case for bottom samples collected at the mouth of Spencer Gulf during February and March 2010, and for bottom samples collected during weak upwelling months (circles in Fig. 16). As a result, temperature- $\mathrm{NO}_{\mathrm{x}}$ and temperature-phosphate relationships of bottom samples on the shelf during strong and weak upwelling events can be represented by quadratic curves (Table 4; Fig. 16). These relationships can help estimate nutrient concentrations from temperatures on the shelf at depth, and can be used from 10 to $16.5^{\circ} \mathrm{C}$. However, once waters are brought into the euphotic zone and nutrients are utilized, these quantifiable relationships no longer exist. In addition, these 


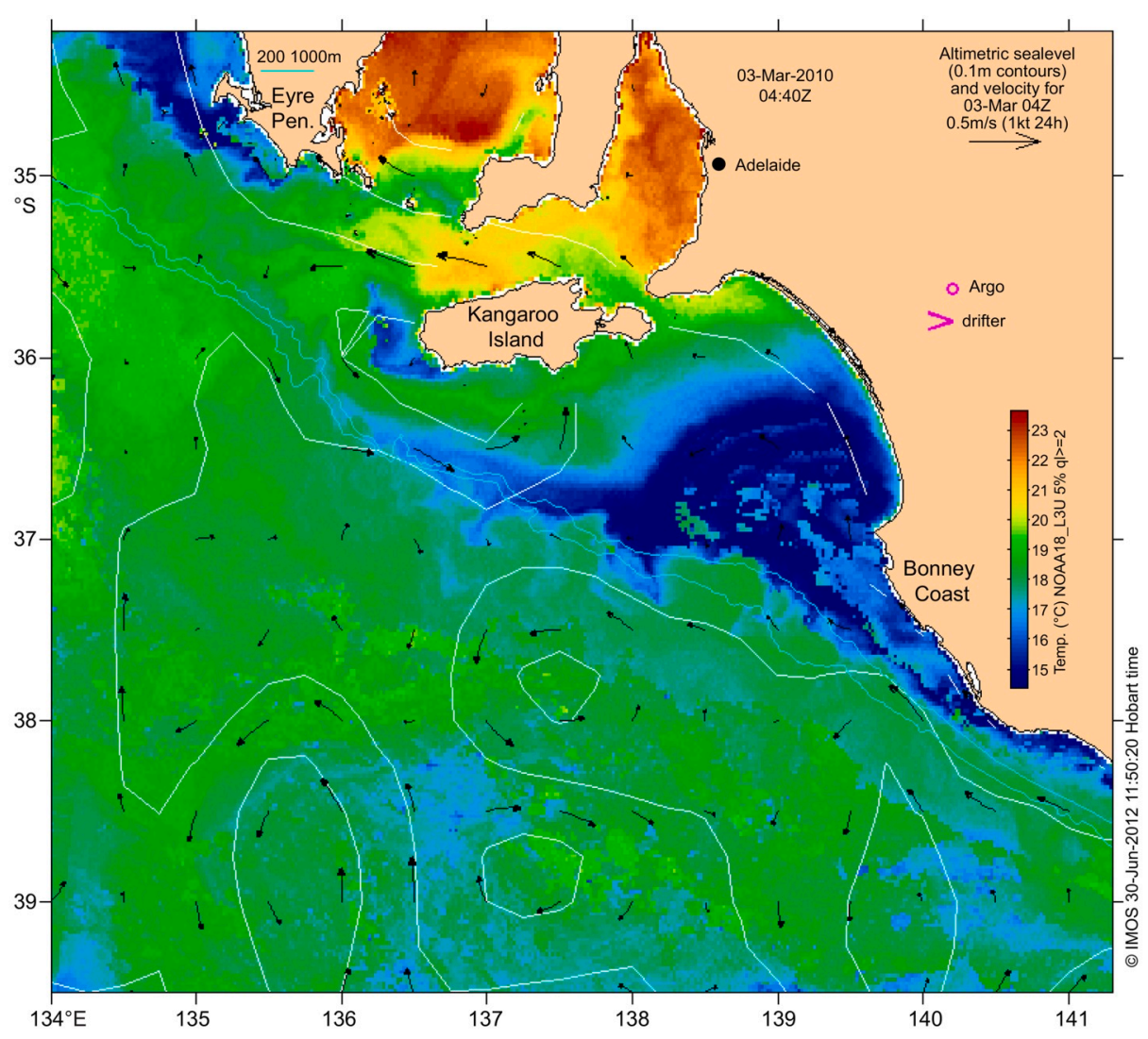

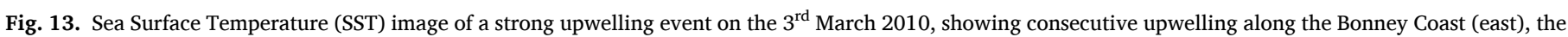
western tip of Kangaroo Island and along the western Eyre Peninsula (Eyre Pen., west). Source: IMOS OceanCurrent (IMOS, 2013).

relationships are useful when upwelled water is on the shelf, but are not applicable during summer months with no upwelling.

The highest values for $\mathrm{NO}_{\mathrm{x}}$ and phosphate were $13.35 \mu \mathrm{mol} / \mathrm{L}$ and $0.94 \mu \mathrm{mol} / \mathrm{L}$ respectively, recorded at $105 \mathrm{~m}$ close to the shelf edge southwest of Kangaroo Island during March 2010 (cross in Fig. 14c). These values are the highest recorded levels on the southern shelf to date. During February and April 2010 values were as high as 9.1 and 8.2 $\mu \mathrm{mol} / \mathrm{L}$ for $\mathrm{NO}_{\mathrm{x}}$ and 0.56 and $0.51 \mu \mathrm{mol} / \mathrm{L}$ for phosphate, respectively. In comparison, typical values recorded during summer months with no upwelling were less than $3.5 \mu \mathrm{mol} / \mathrm{L} \mathrm{NO}$ and less than $0.3 \mu \mathrm{mol} / \mathrm{L}$ phosphate, and typical values for winter months were less than $1 \mu \mathrm{mol} / \mathrm{L}$ $\mathrm{NO}_{\mathrm{x}}$ and less than $0.15 \mu \mathrm{mol} / \mathrm{L}$ phosphate (Fig. 15a). Biological stations located along the $100 \mathrm{~m}$ contour (Fig. 1) indicate a progressive decrease in nutrients as upwelled water flowed west along the shelf bottom towards Eyre Peninsula. Samples at depth south of Eyre Peninsula still had elevated nutrients during strong upwelling months, however, with $\mathrm{NO}_{\mathrm{x}}$ concentrations 4.2-5.3 $\mu \mathrm{mol} / \mathrm{L}$. This was not the case during weak upwelling months; $\mathrm{NO}_{\mathrm{x}}$ concentrations were less than $2 \mu \mathrm{mol} / \mathrm{L}$ and within winter background levels.

The relationship between $\mathrm{NO}_{\mathrm{x}}$ and silicate was more complicated than that of $\mathrm{NO}_{\mathrm{x}}$ and phosphate (Fig. 15b). Silicate levels generally remained low (less than $2 \mu \mathrm{mol} / \mathrm{L}$ ) and did not change significantly between months (Table 3). Only three samples with very high $\mathrm{NO}_{\mathrm{x}}$ (greater than $8 \mu \mathrm{mol} / \mathrm{L}$ ), recorded during March 2010, had silicate levels higher than data recorded during other months (Fig. 15b). Significant variations in the $\mathrm{NO}_{\mathrm{x}}$ :silicate ratio were instead a result of dramatic increases in $\mathrm{NO}_{\mathrm{x}}$ during upwelling months. $\mathrm{NO}_{\mathrm{x}}$ :silicate ratios were high during the strong upwelling months of February and March 2010, with ratios of 4.7:1 and 2.8:1, respectively. In comparison, a ratio of $\sim 1: 1$ was present for the rest of the data. Like the $\mathrm{NO}_{\mathrm{x}}$ :phosphate relationship, upwelling months had stronger linear $\mathrm{NO}_{\mathrm{x}}$ :silicate relationships than winter months. Additionally, the high $\mathrm{NO}_{\mathrm{x}}$ to relatively low silicate signal during upwelling months resulted in negative $\mathrm{Si}^{*}$ values (Fig. 17). $\mathrm{Si}^{*}$ values were as low as $-7.9 \mu \mathrm{mol} / \mathrm{L}$ and $-9.9 \mu \mathrm{mol} / \mathrm{L}$ in February 2010 and March 2010, respectively, indicating that $\mathrm{NO}_{\mathrm{x}}$ was increasing significantly more than silicate during strong upwelling months. Such low $\mathrm{Si}^{*}$ values are representative of Southern Ocean water (Sarmiento et al., 2004), and match values of South Australian Basin Central Water (Richardson et al., 2019).

\subsubsection{Seasonal states}

To compare the degree that shelf nutrients increase during upwelling events, nutrient levels for both winter and summer with no upwelling are here considered as background levels (see Table 3). $\mathrm{NO}_{\mathrm{x}}$ and phosphate increased significantly on the shelf during upwelling months; average shelf values during strong upwelling months were 6.1 times higher in $\mathrm{NO}_{\mathrm{x}}$ and 4.6 times higher in phosphate than winter months. When comparing by water mass, average values of $\mathrm{NO}_{\mathrm{x}}$ were 7.7 times greater in upwelled water (i.e., Slope Water) than in background summer shelf waters (i.e., Subtropical Surface Water), 10.6 times greater than in background winter shelf waters (i.e., winter Subtropical Surface Water), and 36 times greater than in the nutrient depleted summer surface waters (i.e., Evaporated Water). The most nutrient-rich water upwelled on the shelf in March 2010 had $\mathrm{NO}_{\mathrm{x}}$ values 18 times higher and 26 times higher than summer and winter background levels, respectively, and 90 times higher than depleted summer surface waters.

Compared to $\mathrm{NO}_{\mathrm{x}}$ and phosphate, silicate did not show any trend between states (Table 3 ), signifying that upwelled water is relatively low in silicate and upwelling events do not result in increased shelf values, except for the three samples from March 2010 that were also very high in $\mathrm{NO}_{\mathrm{x}}$. Silicate concentrations during winter months rarely dropped below $0.5 \mu \mathrm{mol} / \mathrm{L}$, despite waters being low in $\mathrm{NO}_{\mathrm{x}}$ and phosphate (Fig. 15b). This resulted in winter months having the highest $\mathrm{Si}^{*}$ values of all the seasonal states, with a positive average value (Table 3; Fig. 17). 


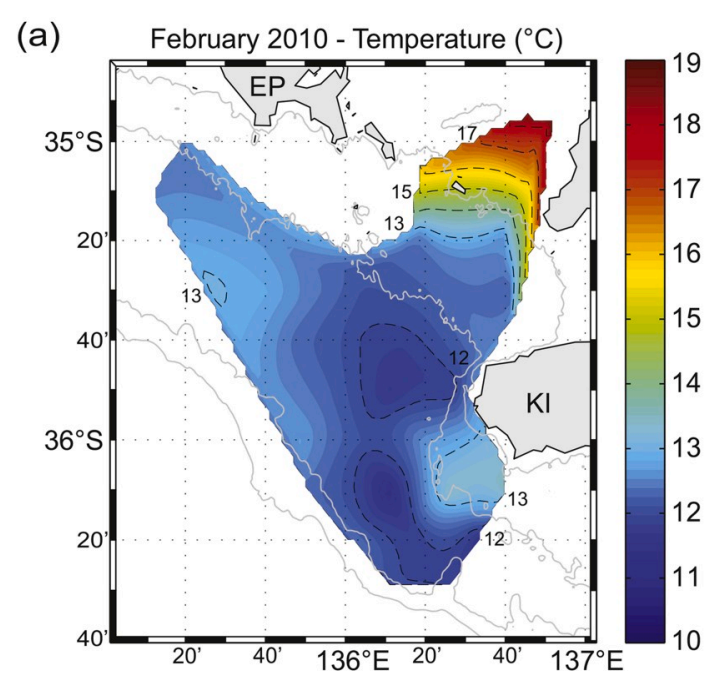

(c)

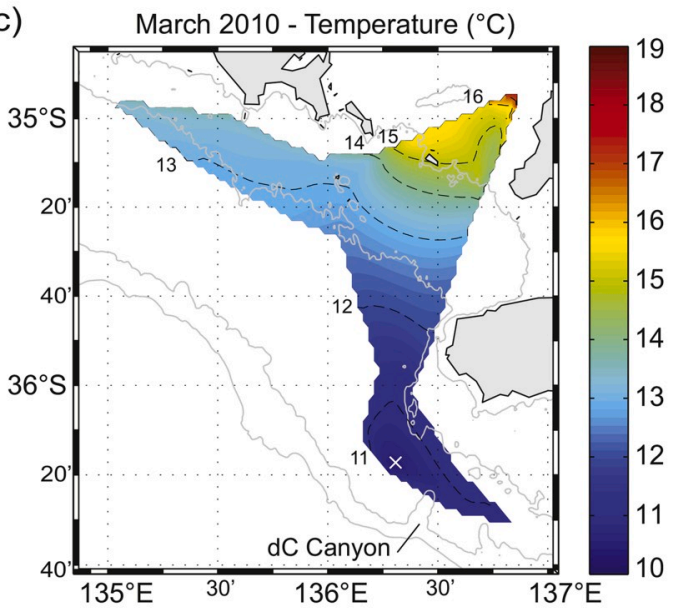

(b)

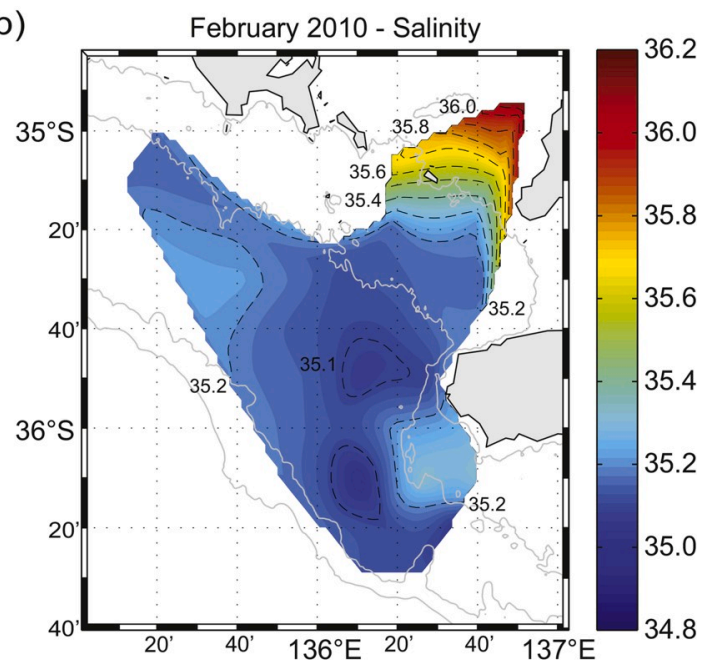

(d)

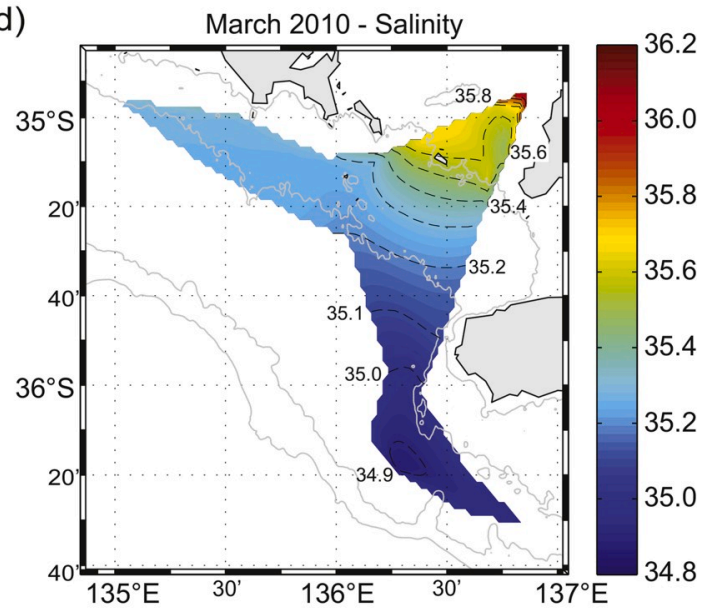

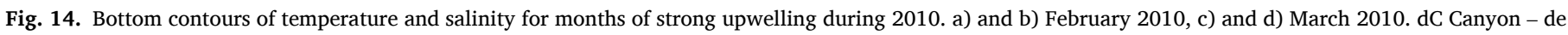
Couedic Canyon. White cross in (c) is the station with lowest temperature and salinity, and highest nutrients, measured in the study.

Table 3

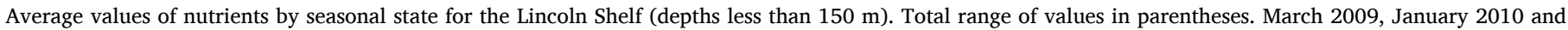
February 2011 were weak upwelling months; February, March and April 2010 were strong upwelling months (no data for February and March 2008).

\begin{tabular}{|c|c|c|c|c|}
\hline Nutrient & Winter months (May-Oct) & Summer months, no upwelling (Nov-April) & Weak upwelling months & Strong upwelling months \\
\hline $\mathrm{NO}_{\mathrm{x}}(\mu \mathrm{mol} / \mathrm{L}$ of $\mathrm{N})$ & $0.50(0-2.42)$ & $0.74(0-3.37)$ & $1.46(0-5.8)$ & $3.19(0-13.35)$ \\
\hline $\mathrm{PO}_{4}(\mu \mathrm{mol} / \mathrm{L}$ of $\mathrm{P})$ & $0.05(0-0.19)$ & $0.06(0-0.25)$ & $0.13(0-0.39)$ & $0.23(0-0.94)$ \\
\hline $\mathrm{SiO}_{2}(\mu \mathrm{mol} / \mathrm{L})$ & $0.86(0.33-1.65)$ & $0.71(0-2.25)$ & $0.88(0.14-2.0)$ & $0.79(0.08-3.45)$ \\
\hline $\mathrm{Si}^{*}(\mu \mathrm{mol} / \mathrm{L})$ & $0.35(-1.08$ to +1.21$)$ & $-0.02(-2.2$ to +1.03$)$ & $-0.58(-4.38$ to +1.08$)$ & $-2.44(-9.9$ to +0.28$)$ \\
\hline
\end{tabular}

Nutrient levels peaked at $\sim 100 \mathrm{~m}$ (Fig. 18) for all summer seasonal states, which is the result of upwelled nutrient-rich Slope Water that lies close to the shelf edge. At this depth, $\mathrm{NO}_{\mathrm{x}}$ concentrations of 3.5-5.8 $\mu \mathrm{mol} / \mathrm{L}$ were present during weak upwelling months, and $\mathrm{NO}_{\mathrm{x}}$ concentrations of $6-13.35 \mu \mathrm{mol} / \mathrm{L}$ were only present during strong upwelling months. The euphotic zone is generally in the upper $60-70 \mathrm{~m}$ during summer in this region (van Ruth et al., 2018), and the bottom boundary of this zone (dashed lines in Fig. 18) can be estimated from the distribution of nutrients during months of weak upwelling: several samples from this state showed elevated nutrients at $\sim 75 \mathrm{~m}$ (Fig. 18a and b), but at shallower depths, only three samples had nutrients above background levels $\left(>1.5 \mu \mathrm{mol} / \mathrm{L} \mathrm{NO}_{\mathrm{x}}\right)$. This suggests that nutrients supplied during weak upwelling events can make it into the euphotic zone but are then very quickly utilized. During months of strong upwelling, elevated nutrients were sustained in the euphotic zone, with 11 samples in the top $70 \mathrm{~m}$ having $\mathrm{NO}_{\mathrm{x}}$ concentrations between 1.9 and $5.7 \mu \mathrm{mol} / \mathrm{L} . \mathrm{NO}_{\mathrm{x}}$ levels greater than $4 \mu \mathrm{mol} / \mathrm{L}$ in the euphotic zone were only present during strong upwelling months (Fig. 18).

Upwelled water at 100-110 m during March 2010 had significantly higher nutrient levels than waters recorded in the February and March slope profiles measured to $365 \mathrm{~m}$ (squares in Fig. 18). During March, $\mathrm{NO}_{\mathrm{x}}$ and phosphate were $7.6 \mu \mathrm{mol} / \mathrm{L}$ and $0.6 \mu \mathrm{mol} / \mathrm{L}$ respectively at 365 $\mathrm{m}$, compared to $9.9-13.35 \mu \mathrm{mol} / \mathrm{L}$ for $\mathrm{NO}_{\mathrm{x}}$ and $0.7-0.94 \mu \mathrm{mol} / \mathrm{L}$ for phosphate at $100-110 \mathrm{~m}$. However, the March profile did not show an upwelling profile like the two February 2010 profiles (e.g., Fig. 7), and it is likely that the nutrient contours were not raised. Based on summer averaged historic data (Richardson et al., 2019), values of $13.35 \mu \mathrm{mol} / \mathrm{L}$ and $0.94 \mu \mathrm{mol} / \mathrm{L}$ for $\mathrm{NO}_{\mathrm{x}}$ and phosphate, respectively, match nutrient 
(a)
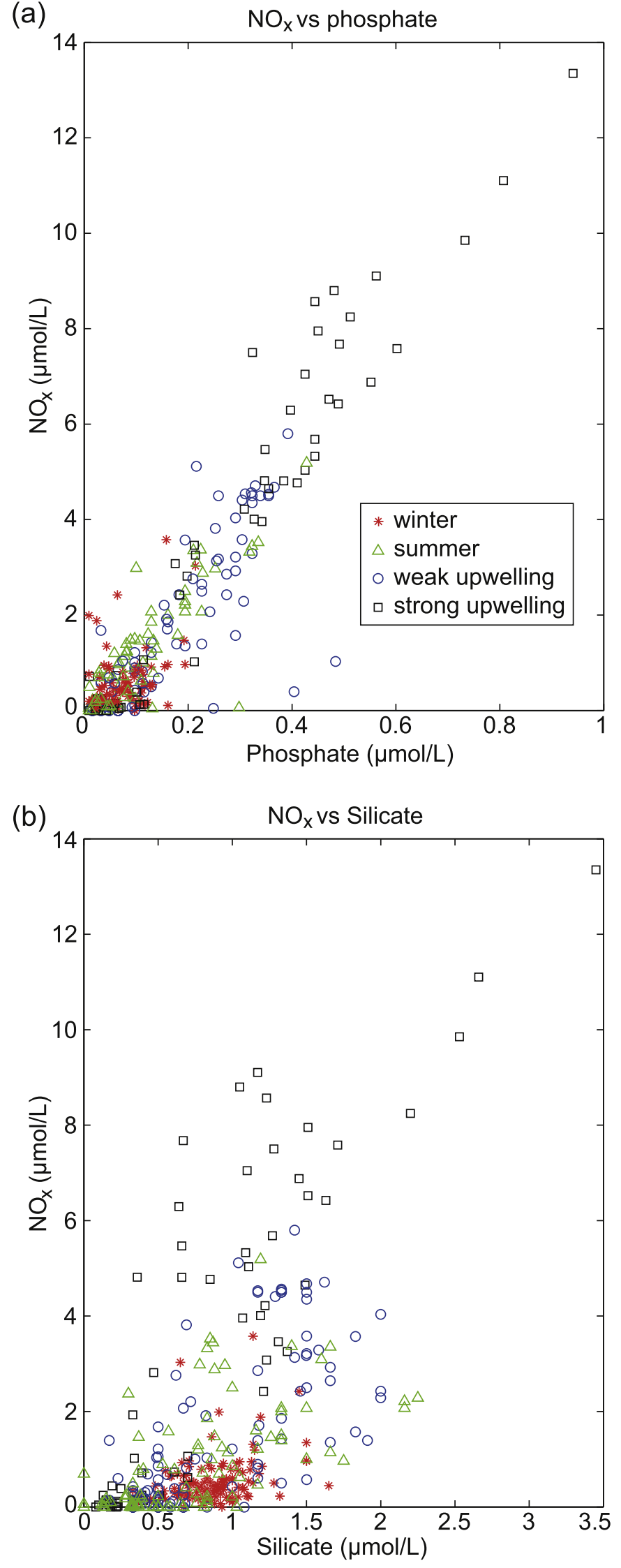

Fig. 15. Nutrient relationships by seasonal state for a) $\mathrm{NO}_{\mathrm{x}}$ and phosphate and b) $\mathrm{NO}_{\mathrm{x}}$ and silicate. $\mathrm{NO}_{\mathrm{x}}$ vs phosphate shows a good linear relationship but $\mathrm{NO}_{\mathrm{x}}$ vs silicate has more variation. values from at least $350 \mathrm{~m}$ in both the Lincoln Shelf and Bonney Coast regions.

\section{Discussion}

\subsection{Depth of upwelling}

Temperature and salinity of waters upwelled onto the Lincoln Shelf during strong upwelling events match the characteristics of off-shelf waters from depths greater than $240 \mathrm{~m}$, based on summer averaged historic data (Fig. 8). For two of the four strong upwelling events, February 2008 and March 2010, the average depth of upwelled water found in slope profiles was $370 \mathrm{~m}$ (Table 2). In addition, the high nutrient values present on the shelf during March 2010 match historic nutrient values from at least $350 \mathrm{~m}$ (Richardson et al., 2019), which matches well with the summer averaged data for temperature and salinity. For these strong upwelling events, water appears to be upwelled over depths of $200 \mathrm{~m}$ or more.

The cold, low salinity, high nutrient water present on the shelf during strong upwelling months was not always found in off-shelf profiles sampled to $365 \mathrm{~m}$. This situation occurred during both March 2008 and March 2010. During the February 2010 cruise, two slope profiles displayed raised isotherms that suggest upwelling (Fig. 7). However, the slope profiles measured in March 2008 and 2010 did not show the same upwelling profile, suggesting that these profiles did no capture upwelling conditions. It is hypothesised that the slope isotherms were no longer raised due to upwelling, or the location along the shelf edge was not close to the upwelling source. The March 2010 profile was sampled three days after the upwelling event, and was to the west of de Couedic Canyon, which is where the upwelling appears to be coming from (Fig. 14c and d).

$\mathrm{T} / \mathrm{S}$ characteristics at $300 \mathrm{~m}$ in the two February 2010 upwelling profiles matched shelf water at $105 \mathrm{~m}$ during March. Nutrient concentrations were not measured in these two raised profiles; however, based on the slope temperature-nitrate relationship (Fig. 16), such water at $300 \mathrm{~m}$ could have similar nutrient levels to those found on the shelf in March. It is possible that isotherms during the March event were similarly raised, but the cruise sampling did not capture the event. Based on this, as well as average depths of temperature, salinity and nutrient values from historic data (Figs. 8 and 16; Richardson et al., 2019), it is a good approximation that isotherms are raised from an average summer depth of $370 \mathrm{~m}$ to $300 \mathrm{~m}$ during strong upwelling events, and water is then upwelled from 300 to $\sim 100 \mathrm{~m}$. Previous literature proposes various source depths of upwelled water, likely due to variations in the strength of different upwelling events. Schahinger (1987) suggests 250-300 m, based on hydrographic sections for the Bonney Coast, which matches well with the depths proposed herein. Modelling of upwelling through submarine canyons by Kämpf (2010), suggests and average of $310 \mathrm{~m}$, which also matches well with depths determined in this study.

\subsection{Upwelling mechanisms and variation between years}

The 2008 and 2010 upwelling seasons were very similar. Lowest temperatures and salinities recorded during both seasons were comparable and matched slope water properties at $370 \mathrm{~m}$ (Table 2), and SST images showed almost identical upwelling plume development and spread from the Bonney Coast west to Kangaroo Island (e.g., Figs. 11 and 13). The 2009 summer season, however, lacked any major upwelling events and had significantly warmer and more saline water on the shelf (Fig. 7).

Upwelling intensity is dependent on both the strength of upwelling favourable winds and the presence of El Niño events in the eastern Pacific (Middleton et al., 2007). Southeasterly winds are upwelling favourable during summer, as they drive a westward shelf current, induce transport of water offshore, and promote upwelling. In addition, El Niño events influence the southern continental shelf and slope by 

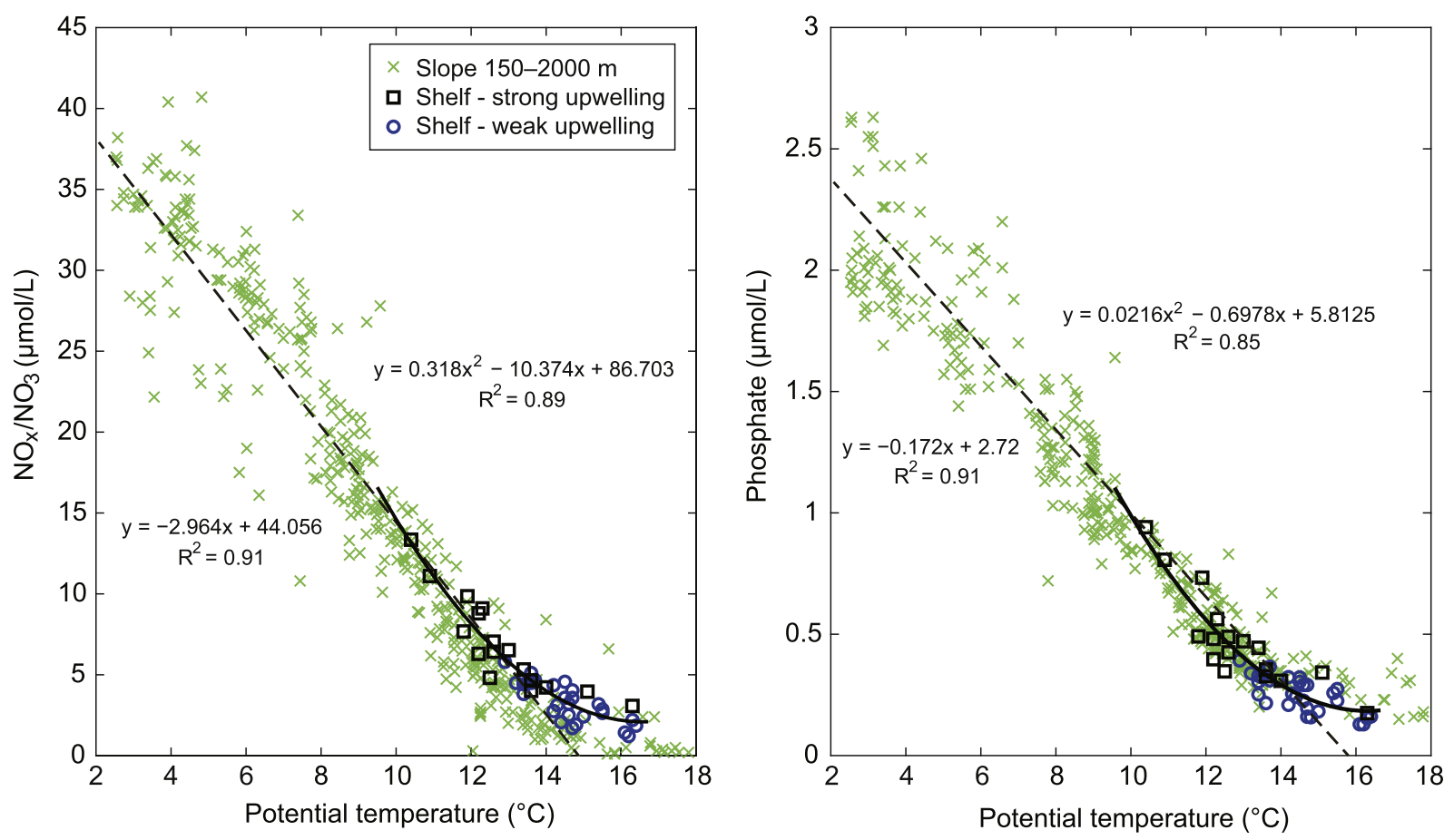

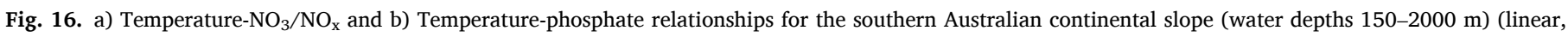

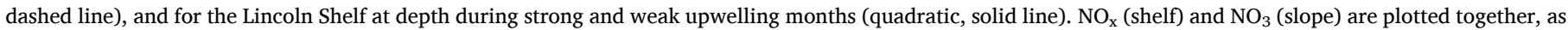
$\mathrm{NO}_{\mathrm{x}} \approx \mathrm{NO}_{3}$ in waters below the photic zone (see text).

Table 4

Quadratic regressions between potential temperature (x) and nutrients (y), for bottom depths on the shelf during weak and strong upwelling months.

\begin{tabular}{|c|c|c|c|c|}
\hline Nutrient & Equation & Potential temp $(\mathrm{x})$ range $\left({ }^{\circ} \mathrm{C}\right)$ & $\mathrm{R}^{2}$ & Standard error of estimate $(\mu \mathrm{mol} / \mathrm{L})$ \\
\hline $\mathrm{NO}_{\mathrm{x}}$ & $\mathrm{y}=0.318 \mathrm{x}^{2}-10.374 \mathrm{x}+86.703$ & $10-16.5$ & 0.89 & 0.85 \\
\hline Phosphate & $y=0.0216 x^{2}-0.6978 x+5.8125$ & $10-16.5$ & 0.85 & 0.07 \\
\hline
\end{tabular}

lowering sea level and raising the thermocline (Middleton et al., 2007). During an El Niño year, downwelling is reduced in winter and upwelling is enhanced the following summer. Wind stress and El Niño Southern Oscillation (ENSO) events appear to be independent of each other (Middleton et al., 2007); ENSO signals are propagated along the wave-guide of the shelf slope from the western Pacific, via Western Australia, rather than through meteorological effects (Li and Clarke, 2004; Middleton et al., 2007). During La Niña conditions, the Leeuwin Current strengthens, the Flinders Current weakens and the thermocline is lowered (Middleton et al., 2007).

La Niña conditions were present during the 2007-2008 and 2008-2009 summer seasons, therefore above average wind stress (Fig. 9) could have been the dominant factor in the February and March 2008 strong upwelling events. Middleton et al. (2007), however, found that significant upwelling occurred in La Niña summers that followed strong El Niño events. They attributed this to either a) weaker wind-forced downwelling in the winter following the El Niño event, resulting in remnant cold water upwelled from the previous year being brought back onto the shelf or b) higher than average upwelling favourable winds. The 2007-2008 summer followed a weak El Niño event in 2006-2007; therefore, it is possible that the strong upwelling event during February 2008 was a combination of above average wind stress and El Niño signals.

Lower than average wind stress in association with La Niña conditions resulted in little to no upwelling during early 2009. An El Niño event began in mid 2009, which would have affected the 2010 summer upwelling season. The occurrence of strong upwelling favourable winds during March 2010 (Fig. 10) resulted in upwelling that was likely enhanced by the El Niño event. Middleton et al. (2007) found that in situ temperature measurements, but not necessarily SSTs, were much colder during El Niño summers. Measured temperatures of $10.5-11.5^{\circ} \mathrm{C}$ at 80-120 m during the El Niño summers 1998 and 2003 were found to be 2-3 standard deviations colder than the mean. These temperatures are comparable to temperatures recorded in this study during the 2008 and 2010 summer upwelling events.

It is likely that a combination of strong upwelling favourable winds and the influence of El Niño signals caused strong upwelling to occur during February 2008 and March 2010, as upwelling characteristics during these two months were remarkably similar. Upwelling favourable winds were below average and variable during January and February 2010 (Fig. 10); therefore, El Niño conditions could have played a role in the persistence of strong upwelling during February and March 2010.

A peak in the upwelling favourable winds in November 2009 (Fig. 10) likely resulted in the low temperature and salinity water present on the shelf during this month (Fig. 6). Despite the difference in T/S conditions between this month and the previous November, no nutrient enrichment was present, suggesting that water was not coming from deep enough to source nutrient-rich slope water from below the oligotrophic mixed layer. Stable isotope data presented by Richardson et al. (2018), as well as historic cruise data, suggest that water on the shelf in November 2009 is coming from the shelf break rather than from deeper water.

For the Bonney Coast, Nieblas et al. (2009) suggest a preconditioning period occurs early in the summer, where variable upwelling-favourable winds weaken the pycnocline, and the Flinders Current raises isotherms 


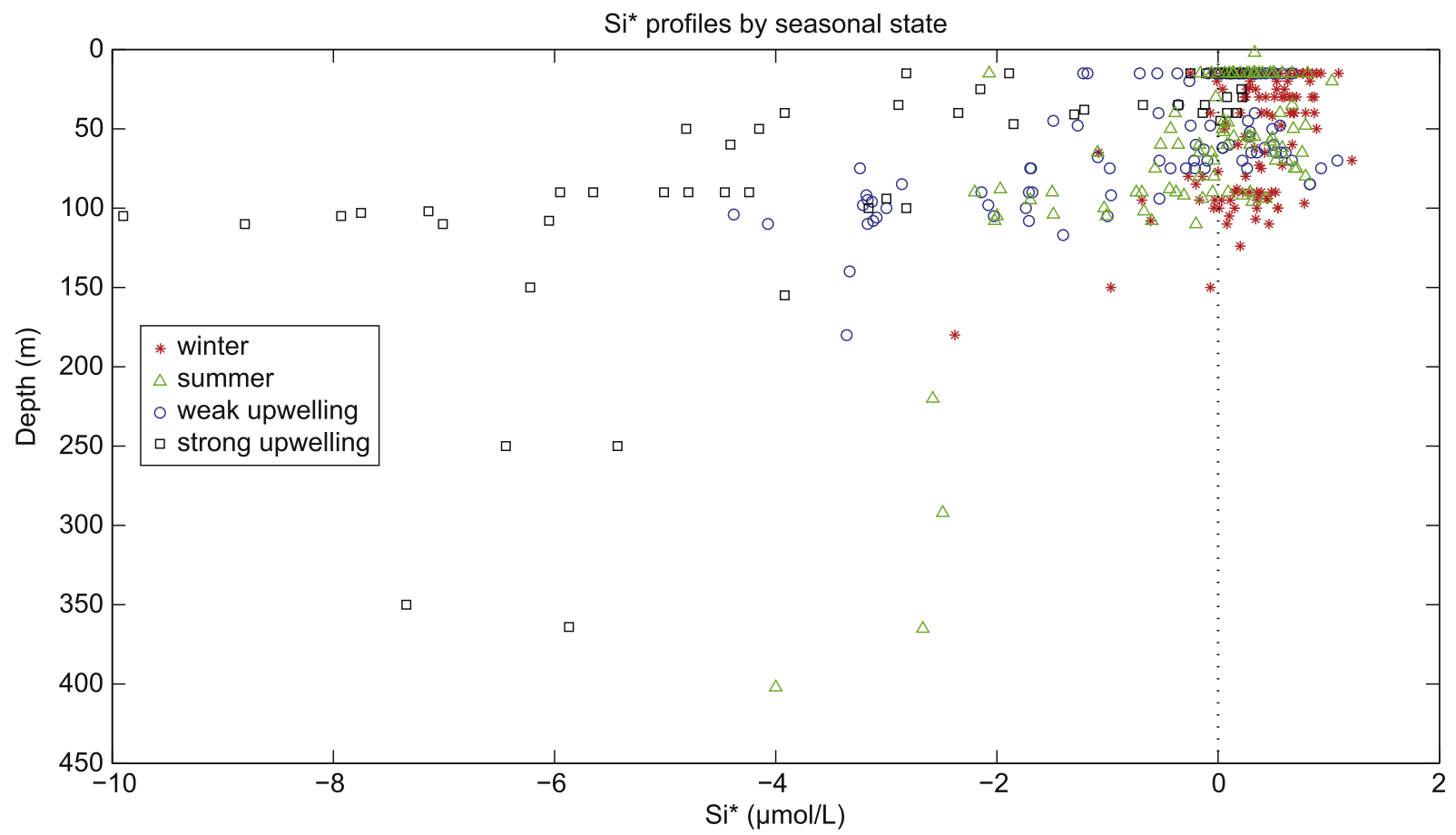

Fig. 17. $\mathrm{Si}^{*}$ profiles by seasonal state. $\mathrm{Si}^{*}=\left[\mathrm{SiO}_{2}-\mathrm{NO}_{\mathrm{x}}\right]$, measured in $\mu \mathrm{mol} / \mathrm{L}$. Months of weak and strong upwelling show very negative values, compared to winter months which have predominantly positive values. Dotted line highlights $\mathrm{Si}^{*}=0 \mu \mathrm{mol} / \mathrm{L}$.
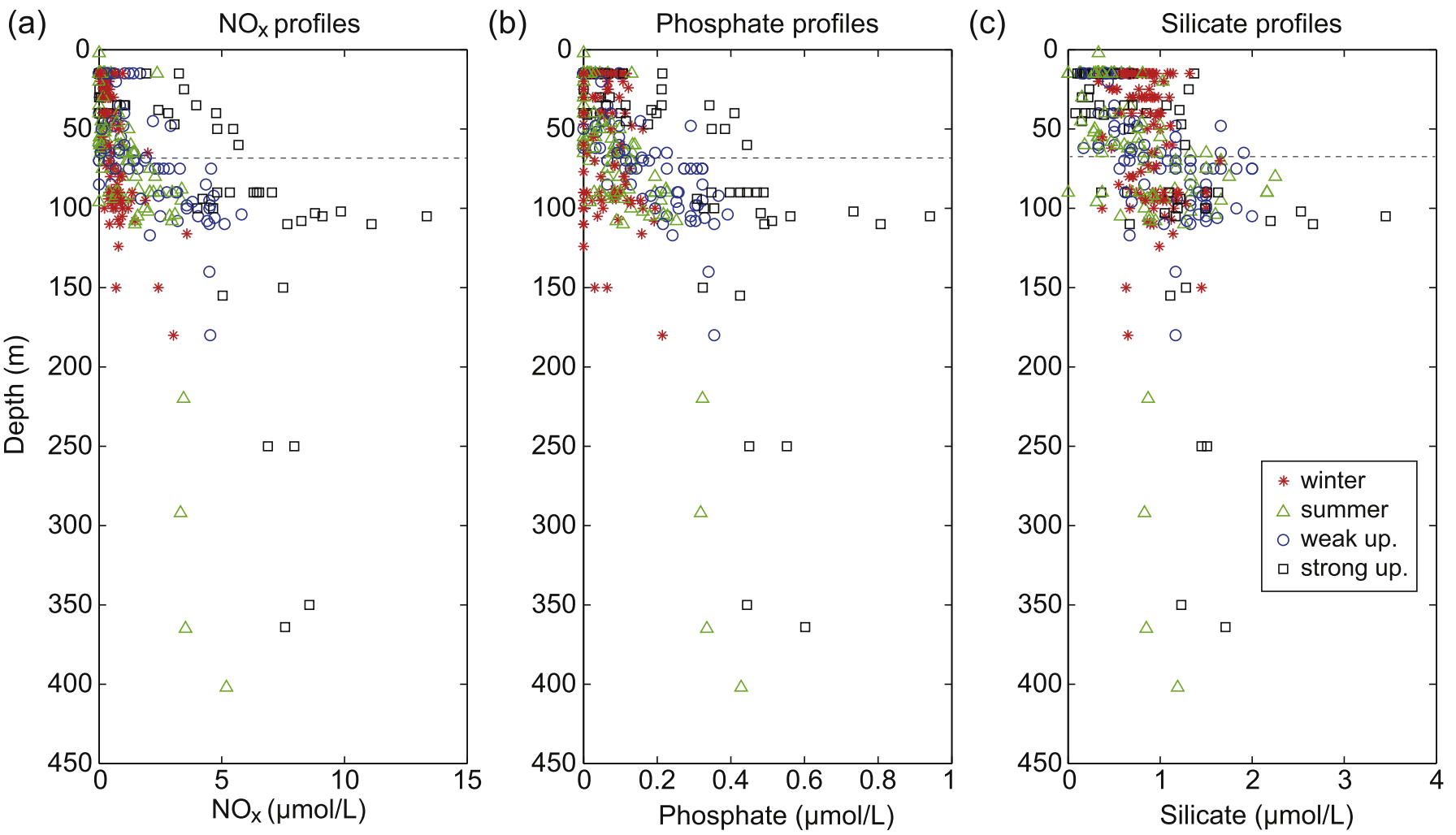

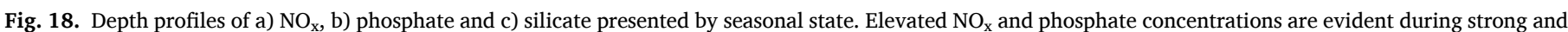

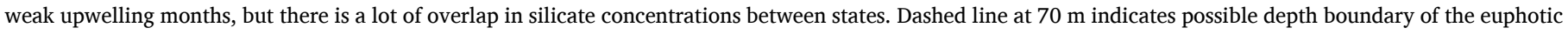
zone; above this line $\mathrm{NO}_{\mathrm{x}}$ and phosphate are much lower, except for samples from strong upwelling months.

(Middleton and Platov, 2003). This would result in nutrient-rich water at shallower depths, to be upwelled later in the summer when upwelling favourable winds were more consistent (Nieblas et al., 2009). Richardson et al. (2019) observed that isotherms were up to $250 \mathrm{~m}$ shallower in summer compared to winter in the upwelling region between the eastern $\mathrm{GAB}$ and the Bonney Coast, due to summer upwelling and winter downwelling, indicating that isotherms shallow and deepen significantly between the two seasons. van Ruth et al. (2018) also discuss 
preconditioning early in the summer, and suggest that the presence of Spencer Gulf outflow could impede upwelled water. However, based on the salinity of bottom water during November 2008 and 2009 (Fig. 6), it is possible that cold, low salinity water can be present across the shelf at depth early in the summer. Outflow deepens the pycnocline over winter (Richardson et al., 2019), however, and the presence of remnant, nutrient-poor outflow on the slope could result in nutrient-rich water sitting deeper in the water column, out of source depth of upwelling early in the summer. Results from this study support a preconditioning period on the shelf early in the summer, where upwelling-favourable winds shallow the pycnocline and nutricline and raise nutrient-rich water on the slope, for it to be within upwelling source depth later in the summer. In addition, cool, fresh bottom water in November, i.e., the early presence of summer conditions, could indicate if strong upwelling and nutrient enrichment is likely to occur later in the summer, as suggested by Richardson et al. (2018).

\subsection{Nutrient enrichment during upwelling events}

Strong upwelling months had the highest values of $\mathrm{NO}_{\mathrm{x}}$ and phosphate, and lowest values of $\mathrm{Si}^{*}$, of any seasonal state, due to upwelling of Slope Water onto the shelf (Table 3; Figs. 15, 17 and 18). Summer months with no upwelling had higher nutrients compared to winter months, due to nutrient-rich water present at the shelf edge, indicating raising of the thermocline during the summer season. In comparison, a well-mixed layer was present down to at least $180 \mathrm{~m}$ during winter months, which blocked nutrient-rich water from reaching the shelf. Nutrient values on the shelf during winter months were typically less than $1 \mu \mathrm{mol} / \mathrm{L}$ for $\mathrm{NO}_{\mathrm{x}}$ and less than $0.15 \mu \mathrm{mol} / \mathrm{L}$ for phosphate, and these results provide a nutrient signature for Subtropical Surface Water transported by the South Australian Current. This water flows east along the southern Australian margin within the top $200 \mathrm{~m}$, and is well mixed from surface to seafloor. Any nutrients are quickly taken up by phytoplankton in the photic zone, resulting in very low nutrient levels. The surface waters in this region have been labelled as oligotrophic overall (Longhurst, 1998), therefore upwelling events bring significant nutrients to support shelf ecosystems and fisheries.

Comparison of average nutrient concentrations for different water masses and states indicates the level of nutrient enrichment that occurs during upwelling events on the Lincoln Shelf. Average shelf values during months of strong upwelling were 6.1 times higher in $\mathrm{NO}_{\mathrm{x}}$ and 4.6 times higher in phosphate than winter months. High nutrient concentrations have been recorded for the Bonney Coast upwelling system to the east of Kangaroo Island (Lewis, 1981), with nitrate concentrations 30-70 times greater in upwelled water compared to background levels of $0.1-0.9 \mathrm{mmol} / \mathrm{m}^{3}$ (equivalent to $\mu \mathrm{mol} / \mathrm{L}$ ). These background levels match well with winter values recorded during this study. Highest values of nitrate on the Bonney Coast were $7 \mu \mathrm{mol} / \mathrm{L}$ (Lewis, 1981), whereas in this study recorded $\mathrm{NO}_{\mathrm{x}}$ values were almost twice that value, reaching as high as $13.35 \mu \mathrm{mol} / \mathrm{L}$ in March 2010.

The most nutrient-rich upwelled water was up to 26 times higher in $\mathrm{NO}_{\mathrm{x}}$ than average winter background values of $0.5 \mu \mathrm{mol} / \mathrm{L}$, and up to 90 times higher in $\mathrm{NO}_{\mathrm{x}}$ than average summer surface water values of 0.15 $\mu \mathrm{mol} / \mathrm{L}$. This is a significant enrichment and the highest recorded to date. To the west of the Lincoln Shelf, in the eastern GAB, Richardson et al. (2009) found nitrate concentrations were higher in upwelled water along the Eyre Peninsula, with nitrate concentrations of $5 \mu \mathrm{mol} / \mathrm{L}$ equivalent to concentrations present at $\sim 250 \mathrm{~m}$ depth. This concentration is still much lower than the $13.35 \mu \mathrm{mol} / \mathrm{L}$ of $\mathrm{NO}_{\mathrm{x}}$ measured southwest of Kangaroo Island during this study. Analysis of productivity levels between upwelling and downwelling events off southwestern Eyre Peninsula by van Ruth et al., 2010 showed highest productivity during upwelling events, but no major variations in macro-nutrients between upwelling and downwelling events. Highest values of $\mathrm{NO}_{\mathrm{x}}$ were $\sim 7$ $\mu \mathrm{mol} / \mathrm{L}$, again much less than concentrations recorded in this study. van Ruth et al. (2010b) hypothesised that upwelling brings micro-nutrients that are being utilized quickly by phytoplankton. Based on results of this study, upwelled water also brings considerable macro-nutrients to the shelf to promote primary productivity in the region.

The nutrient distribution during weak and strong upwelling events, especially the presence of high nutrient concentrations at the base of the euphotic zone during weak upwelling months, suggests that nutrients reach the euphotic zone and are quickly utilized. The euphotic zone is always deeper than the mixed layer in summer when waters are stratified (van Ruth et al., 2018), therefore even during weak upwelling events, nutrient-rich water would be available to autotrophs. This would result in increases in chlorophyll-a concentrations at depth, without having any surface evidence of upwelled water. This is in agreement with conclusions made by van Ruth et al. (2010a, b), who found that high levels of primary productivity occurred even if upwelling did not reach the surface. Differences in nutrient concentrations in the euphotic zone between weak and strong upwelling months are likely a result of: 1) higher nutrient input from deeper upwelling during strong upwelling months, therefore it would take longer for nutrients to be fully utilized, and 2) stronger vertical mixing and incorporation of nutrients into the euphotic zone during strong upwelling events. The latter process is supported by a surface upwelling signal during strong upwelling events that is not present during weak upwelling events, as well as the presence of Slope Water as shallow as $40 \mathrm{~m}$ during February and March 2010 (Richardson et al., 2018). While timing of an upwelling event could influence the level of nutrients measured, the timing of SAIMOS voyages when sampling weak upwelling events was not different relative to when sampling strong upwelling events.

\subsection{Estimating nutrient concentrations during upwelling events}

Temperature and nutrient data show strong correlations in both slope waters and upwelled waters present on the shelf at depth (Fig. 16; Table 4). These relationships provide the potential for estimating the level of nutrients supplied to the shelf during upwelling events. Slope waters have a linear relationship between potential temperature and nitrate or phosphate. Once water is upwelled on the shelf, but before it reaches the euphotic zone, temperatures increase relative to nutrients, and this relationship is best represented by a quadratic curve. Once waters enter the euphotic zone, this relationship is no longer retained.

The three lowest temperature and salinity samples on the shelf match extremely well with the linear relationship of slope waters (Fig. 16). This provides further validation of upwelling source depth; these shelf samples match the $\mathrm{T} / \mathrm{S}$ signature of water at $370 \mathrm{~m}$, and nutrient values of these samples match well with the temperature-nutrient relationship on the slope. There is very limited slope nutrient data for the Lincoln Shelf and Bonney Coast, and as with temperature and salinity, profiles are highly variable. This is especially true for the Lincoln Shelf, where there is not enough data to calculate summer average nutrient profiles. Source depth of upwelling cannot be constrained based on nutrient data alone; however, using available nutrient data in conjunction with summer averaged temperatures (e.g., Fig. 8) and the proposed slope temperature-nutrient relationships (Fig. 16), source depth of upwelling can be validated by temperature, salinity and nutrient concentrations.

It is harder to predict the concentration of nutrients in the euphotic zone during upwelling events; however, understanding bottom water nutrients is a starting point to estimate nutrient availability to phytoplankton. During this study, nutrients were elevated in the euphotic zone during strong upwelling months (Fig. 18), but were low in this zone during weak upwelling months. However, the presence of elevated nutrients at depths below the euphotic zone during weak upwelling months suggests that nutrients were able to reach the euphotic zone, but were being quickly utilized.

Understanding the distribution of nutrients during weak and strong upwelling months can provide information on nutrient enrichment in the eastern GAB. Recording or estimating nutrients both south of Kangaroo Island and south of Eyre Peninsula can predict levels of nutrients 
brought into the euphotic zone during upwelling events off western Eyre Peninsula. Upwelled water from the Kangaroo Island Pool flows west along the shelf bottom, increasing in temperature and decreasing in nutrients as it mixes with shelf waters. South of Eyre Peninsula, nutrient concentrations were elevated during strong upwelling months, but were low and within background levels during weak upwelling months. This suggests that nutrient enrichment south of Kangaroo Island needs to be significant to retain elevated nutrients as waters flow west and are upwelled in the eastern GAB. For weak upwelling events off Kangaroo Island, if these waters were subsequently upwelled along western Eyre Peninsula they would not supply significant nutrients to the euphotic zone.

\subsection{Silicate signature and source of upwelled water}

The ratio of $\mathrm{NO}_{\mathrm{x}}$ to silicate appears to be a good indicator of Slope Water, with high $\mathrm{NO}_{\mathrm{x}}$ : silicate ratios and relatively low $\mathrm{Si}^{*}$ values during months of weak and strong upwelling (e.g., Fig. 17). By comparison, during winter months and summer months with no upwelling, shelf waters had low $\mathrm{NO}_{\mathrm{x}}$ values, less than $4 \mu \mathrm{mol} / \mathrm{L}$, but had silicate values as high as $2.3 \mu \mathrm{mol} / \mathrm{L}$ (Fig. 15b). These silicate values were comparable to the highest shelf values observed throughout the year. This is related to the influence of the Leeuwin Current on Subtropical Surface Water along the southern margin (Richardson et al., 2019), as the Leeuwin Current has a relatively high silicate signature on the west coast of Australia (up to $4 \mu \mathrm{mol} / \mathrm{L}$; Lourey et al., 2006). Relatively high silicate and low $\mathrm{NO}_{\mathrm{x}}$ values of Subtropical Surface Water resulted in positive $\mathrm{Si}^{*}$ values on the Lincoln Shelf during winter and summer with no upwelling influence (Fig. 17).

In comparison, Slope Water on the Lincoln Shelf had low $\mathrm{Si}^{*}$ values due to $\mathrm{NO}_{\mathrm{x}}$ enrichment, which reached a minimum on the shelf of -9.9 $\mu \mathrm{mol} / \mathrm{L}$ in March 2010 (Fig. 17). This is within South Australian Basin Central Water values of -5 to $-10 \mu \mathrm{mol} / \mathrm{L}$ and very close to Tasmanian Subantarctic Mode Water values of $-10 \mu \mathrm{mol} / \mathrm{L}$ (Sarmiento et al., 2004; Richardson et al., 2019). The Southern Ocean has high $\mathrm{NO}_{\mathrm{x}}$ :silicate ratios and low $\mathrm{Si}^{*}$ values, because iron limitation increases silicate uptake by diatoms and results in a relative abundance of nitrate to silicate in surface waters (Franck et al., 2000). The $\mathrm{Si}^{*}$ proxy has been utilized as a conservative tracer of Southern Ocean water masses through the southern hemisphere and into the north Pacific (Sarmiento et al., 2004; Bibby and Moore, 2011), as Si* values in Southern Ocean surface waters are the lowest in the global ocean. The low $\mathrm{Si}^{*}$ of upwelled water confirms the influence of Southern Ocean water masses on the shelf, and has implications for diatom production in shelf ecosystems, as $\mathrm{Si}^{*}$ is a significant control on diatom community structure (Bibby and Moore, 2011).

$\mathrm{Si}^{*}$ values, therefore, are distinctly different for Southern Ocean water and Leeuwin Current water. This proxy can be used to identify Slope Water on the shelf, and provide insight into the influence of both these source waters on the Kangaroo Island region. Temperature, salinity, nitrate and $\mathrm{Si}^{*}$ values of strong upwelling events match properties of South Australian Basin Central Water, which has $\mathrm{T} / \mathrm{S}$ properties of $10-12^{\circ} \mathrm{C} / 34.8-35.1$, and nitrate concentrations of $5-15 \mu \mathrm{mol} / \mathrm{L}$. This water mass is transported by the Flinders Current, and is present along the southern margin of Australia as shallow as $200 \mathrm{~m}$ in the study region (Richardson et al., 2019). Below South Australian Basin Central Water, Tasmanian Subantarctic Mode Water is characterized by a layer of relatively constant temperature and density between $\sim 400$ and $650 \mathrm{~m}$ (Richardson et al., 2019), and therefore upwelling probably does not come from deep enough to directly source this water mass. The coldest and freshest March 2010 upwelled water is, however, very close in attributes to the upper boundary of Tasmanian Subantarctic Mode Water; $\mathrm{T} / \mathrm{S}$ properties of $10^{\circ} \mathrm{C} / 34.8$ and $\mathrm{Si}^{*}$ values less than $-10 \mu \mathrm{mol} / \mathrm{L}$ of the upper boundary of Tasmanian Subantarctic Mode Water presented in Richardson et al. (2019) are very close to $10.4^{\circ} \mathrm{C} / 34.85$ and -9.9 $\mu \mathrm{mol} / \mathrm{L}$ of upwelled water. This highlights the strong association of
Tasmanian Subantarctic Mode Water to upwelling in the Kangaroo Island region. Understanding major and trace nutrient properties of Southern Ocean water masses, which have received much more attention than nutrient studies in the Kangaroo Island region (e.g., Sohrin et al., 2000; Sarmiento et al., 2004; Lai et al., 2008; Petrou et al., 2011; Hassler et al., 2012), will allow for better estimates of nutrient signatures, including minor and trace nutrients associated with subantarctic waters, during future upwelling events, especially if temperature and salinity are the only data available.

\section{Conclusions}

Analysis of four strong upwelling events and several weak upwelling events between February 2008 and February 2011 has provided insight into hydrographic and nutrient properties of upwelled water on the Lincoln Shelf. The upwelling signature at bottom depths is less than $13.5^{\circ} \mathrm{C}$ and 35.3 during weak upwelling events and less than $12.5^{\circ} \mathrm{C}$ and 35.2 during strong upwelling events. Strong upwelling events occurred during February and March 2008 and February and March 2010. The coldest and freshest water recorded on the shelf during the study period had temperatures and salinities of $10.4{ }^{\circ} \mathrm{C}$ and 34.85 , respectively, sampled at 100-110 m during February 2008 and March 2010. Temperature, salinity and nutrient data from this study suggest that upwelling from at least $300 \mathrm{~m}$ is needed to supply such cold, low salinity, nutrient-rich water to the shelf, indicating water is upwelled over depths of $200 \mathrm{~m}$ or more. The average depth of this water recorded in slope profiles from historic summer data is $370 \mathrm{~m}$; therefore, isotherms can be raised significantly during upwelling events.

Upwelled water supplies significant macro-nutrients to an otherwise oligotrophic shelf. Water upwelled onto the shelf during strong upwelling events had very high values of $\mathrm{NO}_{\mathrm{x}}$ and phosphate, up to 13.35 and $0.94 \mu \mathrm{mol} / \mathrm{L}$, respectively, compared to background levels, and supplied significant nutrients to the bottom of the euphotic zone. Robust temperature-nitrate and temperature-phosphate relationships in both slope waters and upwelled shelf waters below the euphotic zone, during weak and strong upwelling events, can allow for nutrient concentrations to be estimated from temperature during future upwelling events. This would greatly increase current understanding of the levels of nutrients supplied to the euphotic zone to be utilized by primary productivity.

Upwelled water was, however, relatively low in silicate and had very low $\mathrm{Si}^{*}$ values, which are both a signature of Southern Ocean water masses. Hydrographic and nutrient properties of upwelled water, as well as the initial depth of such water on the slope, indicates that South Australian Basin Central Water, transported by the Flinders Current System, is brought onto the shelf during strong upwelling events, and that properties are very close to the upper boundary properties of Tasmanian Subantarctic Mode Water. Understanding the source depth and source water mass properties of upwelled water, as well as the potential to estimate nutrients from temperature data, can greatly increase current understanding of nutrient enrichment during strong upwelling events to the generally-oligotrophic Lincoln Shelf. This information allows for better understanding of the impact of such upwelling events on shelf ecosystems and fisheries.

\section{Declaration of competing interest}

The authors declare that they have no known competing financial interests or personal relationships that could have appeared to influence the work reported in this paper.

\section{Acknowledgements}

This research would not have been possible without the generosity of the South Australian Research and Development Institute, who supported the research and facilitated collection of the South Australian Integrated Marine Observing System (SAIMOS) data streams. We thank 
the captain and crew of the R.V. Ngerin during numerous research voyages through all kinds of weather. The SAIMOS hydrographic data is available through the Australian Ocean Data Network (http://imos.org. au/aodn.html). Stable isotope analyses were done with the assistance of Kerry Klassen and April Vuletich in the Queen's Facility for Isotope Research. Support of these analyses was from grants from the Natural Science and Engineering Research Discovery program, the Canadian Foundation for Innovation and the Ontario Innovation Foundation.

\section{References}

Barker, P.M., 2004. The Circulation and Formation of Water Masses South of Australia and the Inter-annual Wind Variability along the Southern Australian Coast. PhD thesis. University of Melbourne, Victoria, Australia, p. 351pp.

Bibby, T.S., Moore, C.M., 2011. Silicate:nitrate ratios of upwelled waters control the phytoplankton community sustained by mesoscale eddies in sub-tropical North Atlantic and Pacific. Biogeosciences 8, 657-666.

Bye, J.A.T., 1972. Oceanic circulation south of Australia. In: Hayes, D.E. (Ed.), Antarctic Oceanology II: the Australian-New Zealand Sector, Antarctic Research Series, 19. American Geophysical Union, Washington D.C., pp. 95-100

Bye, J.A.T., 1983. Physical oceanography. In: Tyler, M.J., Twidale, C.R., Ling, J.K., Holmes, J.W. (Eds.), Natural History of the South East. Occasional Publications of the Royal Society of South Australia, Adelaide, Australia, pp. 75-84.

Coriolis, 2018. ARGO data. These data were collected and made freely available by the Coriolis project and programs that contribute to it. http://www.coriolis.eu.org. (Accessed 23 March 2018).

Csiro, 2020. Historic cruise data. Commonwealth scientific and industrial research organisation (CSIRO). Data provided by CSIRO and reproduced with the permission of CSIRO. Last access 19 February 2020, accessed through the Oceans and Atmosphere Information and Data Centre. https://research.csiro.au/oa-idc/.

Franck, V.M., Brzezinski, M.A., Coale, K.H., Nelson, D.M., 2000. Iron and silicic acid concentrations regulate $\mathrm{Si}$ uptake north and south of the polar frontal zone in the pacific sector of the Southern Ocean. Deep-Sea Res. II 47, 3315-3338.

Goldsworthy, S.D., Page, B., Rogers, P.J., Bulmand, C., Wiebkin, A., McLeay, L.J., Einoder, L., Baylis, A.M.M., Braley, M., Caines, R., Daly, K., Huveneers, C., Peters, K., Lowther, A.D., Ward, T., 2013. Trophodynamics of the eastern Great Australian Bight ecosystem: ecological change associated with the growth of Australia's largest fishery. Ecol. Model. 255, 38-57.

Gruber, N., 2008. The marine nitrogen cycle: overview of distributions and processes. In: Capone, D.G., Bronk, D.A., Mulholland, M.R., Carpenter, E.J. (Eds.), Nitrogen in the Marine Environment. Elsevier, Amsterdam, pp. 1-50.

Hassler, C.S., Sinoir, M., Clementson, L.A., Butler, E.C.V., 2012. Exploring the link between micronutrients and phytoplankton in the Southern Ocean during the 2007 austral summer. Front. Microbiol. 3, 26pp. Article 202.

HATCH, 2003. HATCH Company/Lachat Instruments Quikem Methods. Lachat Instruments, Colorado, USA.

IMOS, 2013. SST images. The Integrated Marine Observing System (IMOS). IMOS is a national collaborative research infrastructure, supported by Australian Government. Accessed on 23 December 2013 from IMOS OceanCurrent. http://oceancurrent.im os.org.au.

Kämpf, J., Doubell, M., Griffin, D., Matthews, R.L., Ward, T.M., 2004. Evidence of a large seasonal coastal upwelling system along the southern shelf of Australia. Geophys. Res. Lett. 31, L09310.

Kämpf, J., 2010. On preconditioning of coastal upwelling in the eastern Great Australian Bight. J. Geophys. Res. 115, C12071.

Lai, X., Norisuye, K., Mikata, M., Minami, T., Bowie, A.R., Sohrin, Y., 2008. Spatial and temporal distribution of $\mathrm{Fe}, \mathrm{Ni}, \mathrm{Cu}$ and $\mathrm{Pb}$ along 140 degrees $\mathrm{E}$ in the Southern Ocean during austral summer 2001/02. Mar. Chem. 111, 171-183.

Lewis, R.K., 1981. Seasonal upwelling along the southeastern coastline of SouthAustralia. Aust. J. Mar. Freshw. Res. 32, 843-854.

Li, J., Clarke, A.J., 2004. Coastline direction, interannual flow and the strong El Niño currents along Australia's nearly zonal southern coast. J. Phys. Oceanogr. 34, 2373-2381.

Longhurst, A., 1998. Ecological Geography of the Sea. Academic Press, San Diego, p. 398pp.

Lourey, M.J., Dunn, J.R., Waring, J., 2006. A mixed-layer nutrient climatology of Leeuwin Current and Western Australian shelf waters: seasonal nutrient dynamics and biomass. J. Mar. Syst. 59, 25-51.
Martiny, A.C., Pham, C.T.A., Primeau, F.W., Vrugt, J.A., Moore, J.K., Levin, S.A., Lomas, M.W., 2013. Strong latitudinal patterns in the elemental ratios of marine plankton and organic matter. Nat. Geosci. 6, 279-283. https://doi.org/10.1038/ NGEO1757.

McCartney, M.S., Donohue, K.A., 2007. A deep cyclonic gyre in the Australian-Antarctic Basin. Prog. Oceanogr. 75, 675-750.

McClatchie, S., Middleton, J.F., Ward, T.M., 2006. Water mass analysis and alongshore variation in upwelling intensity in the eastern Great Australian Bight. J. Geophys. Res. Oceans 111, C08007.

McLeay, L.J., Sorokin, S.J., Rogers, P.J., Ward, T.M., 2003. Benthic Protection Zone of the Great Australian Bight Marine Park: 1. Literature Review. South Australian Research and Development Institute (Aquatic Sciences), West Beach, South Australia, Australia, p. 70pp.

Middleton, J.F., Cirano, M., 2002. A northern boundary current along Australia's southern shelves: the Flinders Current. J. Geophys. Res. Oceans 107, 3129.

Middleton, J.F., Platov, G., 2003. The mean summertime circulation along Australia's southern shelves: a numerical study. J. Phys. Oceanogr. 33, 2270-2287.

Middleton, J.F., Bye, J.A.T., 2007. A review of the shelf-slope circulation along Australia's southern shelves: Cape Leeuwin to Portland. Prog. Oceanogr. 75, 1-41.

Middleton, J.F., Arthur, C., van Ruth, P., Ward, T.M., McClean, J.L., Maltrud, M.E., Gill, P., Levings, A., Middleton, S., 2007. El Niño effects and upwelling off south Australia. J. Phys. Oceanogr. 37, 2458-2477.

Nieblas, A.-E., Sloyan, B.M., Hobday, A.J., Coleman, R., Richardson, A.J., 2009. Variability of biological production in low wind-forced regional upwelling systems: a case study off southeastern Australia. Limnol. Oceanogr. 54 (5), 1548-1558.

Petrou, K., Hassler, C.S., Doblin, M.A., Shelly, K., Schoemann, V., van den Enden, R., Wright, S., Ralph, P.J., 2011. Iron-limitation and high light stress on phytoplankton populations from the Australian Sub-Antarctic Zone (SAZ). Deep-Sea Res. II 58, 2200-2211.

Richardson, L.E., Kyser, T.K., James, N.P., Bone, Y., 2009. Analysis of hydrographic and stable isotope data to determine water masses, circulation, and mixing in the eastern Great Australian Bight. J. Geophys. Res. 144, C10016.

Richardson, L.E., Middleton, J.F., Kyser, T.K., James, N.P., Opdyke, B.N., 2018. Water masses and their seasonal variation on the Lincoln Shelf, South Australia. Limnol. Oceanogr. 63 https://doi.org/10.1002/lno.10817, 1944-1963.

Richardson, L.E., Middleton, J.F., Kyser, T.K., James, N.P., Opdyke, B.N., 2019. Shallow water masses and their connectivity along the southern Australian continental margin. Deep-Sea Res. I 152. https://doi.org/10.1016/j.dsr.2019.103083.

Ridgway, K.R., Condie, S.A., 2004. The 5500-km-long boundary flow off western and southern Australia. J. Geophys. Res. Oceans 109, C04017.

Rochford, D.J., 1986. Seasonal changes in the distribution of Leeuwin Current water off southern Australia. Aust. J. Mar. Freshw. Res. 37, 1-10.

SAIMOS, 2012. Cruise and Mooring Data. Southern Australian Integrated Marine Observing System (SAIMOS). South Australian Research and Development Institute (Aquatic Sciences), West Beach, South Australia, Australia. IMOS is a national collaborative research infrastructure, supported by the Australia Government. Data available through the Australian Ocean Data Network. http://imos.org.au/aodn.htm 1.

Sarmiento, J.L., Gruber, N., Brzezinksi, M., Dunne, J., 2004. High latitude controls of thermocline nutrients and low latitude biological productivity. Nature 426, 56-60.

Schahinger, R.B., 1987. Structure of coastal upwelling events observed off the South-east coast of South Australia during February 1983-April 1984. Aust. J. Mar. Freshw. Res. 38, 439-459.

Sohrin, T., Iwamoto, S., Matsui, M., Obata, H., Nakayama, E., Suzuki, K., Handa, N., Ishii, M., 2000. The distribution of Fe in the Australian sector of the Southern Ocean. Deep-Sea Res. I 47, 55-84.

van Ruth, P.D., Ganf, G.G., Ward, T.M., 2010a. Hot-spots of primary productivity: an Alternative interpretation to Conventional upwelling models. Estuar. Coast Shelf Sci, 90, 142-158.

van Ruth, P.D., Ganf, G.G., Ward, T.M., 2010. The influence of mixing on primary productivity: a unique application of classical critical depth theory. Prog. Oceanogr. 85, 224-235.

van Ruth, P.D., Patten, N.L., Doubell, M.J., Chapman, P., Rodriguez, A.R., Middleton, J. F., 2018. Seasonal- and event-scale variations in upwelling, enrichment and primary productivity in the eastern Great Australian Bight. Deep Sea Res. II 157-158, 36-45.

Ward, T.M., McLeay, L.J., Dimmlich, W.F., et al., 2006. Pelagic ecology of a northern boundary current system: effects of upwelling on the production and distribution of sardine (Sardinops sagax), anchovy (Engraulis australis) and southern bluefin tuna (Thunnus maccoyii) in the Great Australian Bight. Fish. Oceanogr. 15, 191-207. 